Portland State University

PDXScholar

7-25-1973

\title{
The origin of property in land: Paul Vinogradoff and the late XIXth century English historians
}

Caroline Phillips Stoel

Portland State University

Follow this and additional works at: https://pdxscholar.library.pdx.edu/open_access_etds

Part of the Cultural History Commons, European History Commons, and the Other History Commons Let us know how access to this document benefits you.

\section{Recommended Citation}

Stoel, Caroline Phillips, "The origin of property in land: Paul Vinogradoff and the late XIXth century English historians" (1973). Dissertations and Theses. Paper 1672.

https://doi.org/10.15760/etd.1671

This Thesis is brought to you for free and open access. It has been accepted for inclusion in Dissertations and Theses by an authorized administrator of PDXScholar. Please contact us if we can make this document more accessible: pdxscholar@pdx.edu. 
AN ABSTHCT OF TUE TUESIS or Caroline thillips Stoel for the Hater of Arts in bistory presented July 25, 1973.

Titie: The Origin of Property in Land: Paut Vinogradoff and the Late XIXth Century English Hetstorias.

AYPROVED QY MEMBERS OF THE THESIS CORMITTEE:

Michaei F. Rearion

Thonas D. Mortis

Garies A. LeGuin

One of the problems which has ingrigugd English historans for over a hundred years is that of the position of the conwon man in early England. Was he a Eneeman, working land held comburaly by lhe village, or was he a serf labortug upon the land of an overlord? Since this question of freedorn is fnextricabiy interwoven whin landholding concepts the problem may also be stated cnothex way: Did private property in Jand exist frow the earlest rines, or is that instituton the result of centuries of appropiation by individuals of iand originally belonging to the comuntey as a whole? 
In the late 19 th century a group of English hiscorians devoted themselves to the study of this problem. The conclusions they reached varied considerably. The purpose of this essay is to examine some of those conclusions and the suppositions upon which they rest, and to attempt to find methodological and ideological differences which may account for the varied results. The study will focus upon Paul Vinogradoff (1854-1925), legal historian and jurisprudential scholat: whose best knom works are concerned with this subject.

Toward the end of the 18th century there depeloped in Germany a theory of the beginnings of society, known as the Mark cheowy, which described those beginnings as an ldyljic neriod when wanklad lived together in free communtses. English historlans found this thesis much to their Ilking: it ficted well. with Eiglinh iala and democracy, and it supported popular belief in a strong cemanic: rather than Roman, influence in the development of English institutions. Beginning with John M. Kemble's Saxons in England in 1849, Eng IIsh historians almost to a man accepted the theory without critfcal examination of the authorities upon which tt resced. In 1883, however, an anateur historian, Frederic Seebohm, in The English Village Community, challenged the Mark theory and asserted that the English common man was originally a serf laboring on an estare which strongly resembled the Roman villa. Paul Vinogradoff, a ralented Russian work ing in England on early agraxian history, sought new proof to sustain the cause of the common free man. In Villaingge In England (1892) he atcempted to prove that the early villein was free both legally and econonically. He was supported by Frederic Mait Iand in Domesday Book 
and Beyond (1897), who found in the Dousday survey proof of vestigal freedom, which he heId could only mean that the once free villein had lost much of his liberty durine the late Anglo-Saxon period, and that his subjection was completed by the Noman conquerors. Willian Ashley, in several works, supported Seebohm's position, but didnot always agree with him.

All four historians were products of conservative backgromes. There were, however, differences in the more intinate decals of their soctal surroundings, differences of family, education, religlon, and in the case of vinogradoff, of national origin. Vinogradoff and Mattand came from economically secure families, who provided for then the best education available; thoy vere religious agnostics:

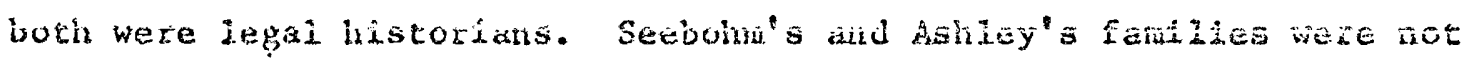
affluenst, and the education they obtalned cane primarily from.thelr own efforts; boch were devout nembers of evangelical fatths; Ashley was an econonte historian and Seebohm's best works were in the field of early agrarian history.

Each of these men read the sparse evidence available on the subject Erom a particular polnt of view. Vinogradoff and Mattland concluded that the early English peasant was free and that his fall from freedom to serfdom during the lace Anglo-Saxon and early Norman periods was due to a large extent to a misinterpretation of his legal status. Seebohm and Ashley held he had been a serf from the time of the Teutonic sertlements, and that his legal rights were never as important as his economic postition. 
TO THE OFFICE OF GRADUATE STUDYYS AND RESEARCH:

The members of the comitcee approve the thests of Caroline Phillps Stoel presenced July 25, 1973.

\author{
Michael F. Reardon \\ Thomas D. Morxis
}

Charies A. Le Guir

APSROVED:

Jegpe L. Gismore, Head, Department of HAstory

Dabid T. Clark, Dean of Graduate studies and Reseatch

Ju1.y 27, 1973 
THE ORIGIN OF PROPERTY IN LAND:

PAUL VINOGRADOFF AID THE LATE XIXTh CENTURY ENGISISH HISTORIANS

by

CAROLINE PHILLIPS STOEL

A thesis submited in parlial fulfillinent of the requirements for the degree of

MASTER OF ARTS

in

HISTORY

Portiand State University

1973 
TABLE OF CONTENTS

CHAPTER

PAGE

$\begin{array}{ll}I \text { INTRODUCTION } & 1\end{array}$

II THE PROBILM: FRE EMAN OR SERF 10

The European Backgrouna $\quad 10$

The German Historians 10

The French Histortans 17

The English Background $\quad 21$

John M. Kanb2e:

The Sagons fri England 22

Uenry Madne:
Villare Commolites East and hest

The Oritord School: 31

W11iam stubbs

Edward A. Freeman 35

John $R_{a}$ Green 37

II THE HTSTORYANS: IEGA AIVD ECONOMTC 39

- Frederic Ssebohn 39

Paul Vinogradoff $\quad 51$

'Hosnitae Britannae Gratus Advena' 51

V1llatnage In England $\quad 57$

Frederic Maitland $\quad 67$

Whlinan Ashley

IV TUE VICTORIAN FRA: TDEOLOGI AND INELUENCF

Politics and Ideas - 89

Society and Education $\quad 101$ 
Frederic Seebohn 101

Paul V1nogradoff

104

Frederic Maitland

116

William Ashley

120

V CONCLUSION

12.4 
CHAPTER I

\section{INTRODUCTION}

One of the problems which has intrigued English bistorians for over a hundred years is that of the position of the common man in eariy England. Was he a free man, working land held communally by the village, or was he a serf laboring upon the land of an overiord? Since this question of freedon is inextricably interwoven with landhojding concepts the problem may also be stated another way: Did privace property in land exist from the earliest times, or is that: institution the result of centuries of appropriation by individuals of land oxiginally belonging to the community as a whole?

In the late 19 th century a group of English historians devoted themselves to the study of this question. The conclusions they reached varied considerably: The purpose of this essay is to examine some of those conclusions and the suppositions upon which they rest, and to attempt to find methodological and ideological differences which may account for the varied results. The study will focus upon Paul Vinogradoff, legal historian and jurisprudential scholar, whose best known works are concerned with this subject.

Two principal difficulties confront the historian who seeks a solution to the puzzle of English beginnings. The first is how to deal. with the many aspects--social, economic, and legal-mof the question. Most historians have concentrated on one aspect at the expense 
of others. Thus we find legal historians tend to offer chiefly legal interpretations of the issues involved, and economic historians primarily economic ones. Yet it is not enough to propose an answer drawn from an investigation of only one of these aspects, for ary final conclusion must depend upon full considexation of them all. In the second place, there is a lack of any solid evidence to support either hypothesism-beginnings in freedom or beginnings in serfidom and this has led to much specislation based on hindsight, and sometimes to completely opposing interpretations of contenporary writings and documents, as well as of the non-documentary evidence.

Let us look briefly at the materials avallable. The historian can begin eithex with the docunents of the Norman period, starting with Domesday Book in 1086, and proceed backwards from the known to the unknown, or he can begin with the writings of Caesar (De Beilo Gallico, 50-58 B.C.) and Tacitus (Gemania, 98 A.D.) which describe Institutions of the early Germanic peoples who settled England. Between these two sources in time are Bede's Ecclesiastical History (731), the literature, heroic poetry, laws, and charters of the AngloSaxon period. Other kinds of evidence consist of language, place names, archaeojogical remains, and land cultivation patterns. Most of this evidence is indirect and provides no clear answer to our question, for the salient features of the land story are not written plainly upon efther the topograpty of the land or the face of the documents. 1

${ }_{1}$. R. Denman, Origins of Ownership (London: George Allen E. Unwin, 1958), p. 44 . 
The problem has been debated chiefly in terms of the influence of Germanic as opposed to Roman culture in early medieval Europe and England. 2 What manners and customs did the Teutonic invaders bring with than to the islands of Britain? In what kind of settlements did they live? Did they take over the Roman manors, beconing substitute lords over the subservient Celts, or did they create purely Germanic settlements wiping out the remaining Ronan culture along with most of the Celtic population? What is the meaning of the land cultivation patterns? Was the prevalent field system of Celtic origin, or was it brought to Britain by the Teutons? Were the land strips indicative of communal or manorial life? or perhaps of small holdings of individual property?

Iha non-documentary evidence is inconclusive. Language and place nancs can only prove that the Germanic peoples ultimately became the dominant race, not that they immediately became landlords, nor that they substantially destroyed the Celtic peoples. ${ }^{3}$ Archaeological remains point both to "prior Saxonization" of Roman Britain, and to the continuation of Romano-Briton culture after the departure of the Roman legions. 4

${ }^{2}$ E. Lipson, The Econonic History of England ( 3 vols; 12 th ed.; New York: Baxnes \& Noble, 1959), Vol. I, pp. 1-31; 1. R. Loyn, Ang lom Saxon England and the Norman Conquest (London: Longmans, Green \& Co., 1962), pp. 1-63.

3"rhe English have never been good linguists, and no Englishman will be at pains to learn welsh if he can help it." H. P. R. Finberg (ed.), The Agrarjan History of England and Wales, A.D. 43-1042 (Cambridge: viniversity Press, 1972), p. 389.

4lbid., pp. $250 \mathrm{ff}$. 
Land cultivation patterns have been the subject of much debate and rivers of ink have flowed in attempes to explain then. Two definite patterns are still clearly visible in many parts of Britain. One is composed of small square or rectangular fields, and the other corsists of large open fields divided into long narrow strips, arranged often at odd angles giving the overall appearance of a great patchwork quilt. The assumpion for many years was that the smaller fields were the prevalent type of cultivation prior to the Teutonic invasions and that the large open strip fields appeared with the sectlement of the Germanic peoples in England. The type of plough used by the different races was satd to account for the distinct kinds of culcivation. 5 More recently chis assumption has been rejected by histor lans who claim the two ficld types cannot be classified as pre-saxon and Saxon, but that they probably existed sinultaneously and were due simply to the differences in the layout of the ground under cultivation. 6 Atrempts to explain the striking patterns made by the long, narrow strips of the great open fields have resulted in an even more fundamental disagreement: one group holds the strips were the result: of a conscious effort to maintain social and political, as rell as

5Marc Bloch, French Rural History, trans. I. Sondheimer (Berkeley: University of California Press, 1966), pp. 50ff; F. B. A. Collingwood and J. is. L. Myres, Romin Britain and the English Scttiements (Oxford: Clarendon Press, 1968), pp. $210 \mathrm{ff}$

${ }^{6}$ Finberg, pp. 259ff; G. O. Sayles, The Medieval Foundations of England (London: Meuthen \& Co., 1956), p. I18; Co S. and C. S. Onvin, The Open Fields (Oxford: Clarendon Press, 1967), pp. 10fi. 
economic, equality; ${ }^{7}$ the other contends they were only the consequence of practical cooperative husbandry. 8

Bede's Ecclestastical History, the Arglo-Sayon Chronicle, and other literature of the period are all beset with obscurietes. These sources were for the most part neglected by 19 th century historians witing on problems of property and freedom. 9 This failure has been sharply criticized by later writers who claim that literary sources, especially Bede's Mistory and the heroic poens in Beowulf, reveal a different and more trustworthy picture of early English sociecy than do Tacitus' Germania, place names, and Saxon Iaws--traditional source matcrials of the institutional historian. 10

Land laws and charters are abundant from the 7 th century onward, but they are often equivoca?, somerjmes fragmentary. The contents of a particular document may relate to a lccal custom, a regional precedent, or an innovation; the document in question may be a contract, a conveyance, or a wil1-min form it is apt to be imprecise.

7F. M. Stenton, Anglo-Saxon England, c. 550-1087, Vol. II of The Oxford History of England, cd. G. N. Clark (15 vols.; Oxford: Clarendon Press, 1936-65), pp. 276ff.

8 orwin and orwin, pp. 60-61.

${ }^{9}$ Among institutional historians John $M_{\text {. }}$ Kemble made the most extensive use of 1iterary sources in Saxons in England (2 vols.; London: Longmans, 1849). Infra, p. 28. .

$10 \mathrm{H}$. M. Chadwick, The Origin of the English Nation (Cambridge: University Press, 1907), FP. 154-58; R. H. Hodgkins, The History of the Anglo-Saxons (2 vols; 3rd ed.; London: Oxford University Press, 1952), Vol. I, pp. 201ff. 
ilechical terms abound in both legislation and charters and these often prove difficult to translate into modem idion.

Differences in interpretation may be illustrated by taking as an exainple one of the laws or 'dooms' of Ine, king of Wessex, promulgated axound the year 694 .

If ceorls have a common madow or other share land to enclose, and some have enclosed their share while others have not, let those to whom the gap is due go to the others who have enclosed their share and make amends to them. 11

This law has been held to be evidence showing the ceorls of this period were freemen, engaged in cooperative cultivation of thei $x$ individual plots of land, responsible to no lord, but only to the king for a breach of local custom. 12 on the other hand the same law has been cited as proof of commul agricultural practices followed by the peasant farmers under the supervision of a lord. 13 The law has also been said to be early documentary evidence of the existence of "common intemixed arable acres in England", 14 and conversely, to suggest that "each man's share lay in one block rather than in intermixed strips." 15

The first land charters were royal grants of land, made most often to ecclesiastical institutions, but sometimes to laymen as we11.

$$
\begin{aligned}
& 11_{\text {Stenton, pp. } 276-77} \\
& 12_{\text {Ibid., p. }} 2.77 .
\end{aligned}
$$

$13 \mathrm{~F}$. Seebohm, Ihe English Viliage Communtty (Port Washington, N.Y.: Kennikat Press, 1971); p. 110.

${ }^{14} \mathrm{H}$. L. Gray, English Mield Systems (Cambridge, Mass.: Harvard University Press, 1959$),$ p. 52 .

15 Finberg, p. 489. 
The earliest of these, dating back to the beginning of the 7 th century, were witten in Latin, with the description of the Iand granted usually in English, and were generally rather vague in outline. ${ }^{16}$ The later charters of the 10 th and 11 th centuries witnessed transfers of land both by kings, and by those holding lands by grants from the king or one of his grantees, to churches, monasteries, abbeys, and to laymen in return for specified services. During this period the charters were nomally written entirely in English, had assumed a fairly definite form, and marked a type of landholding called 'bookland' which had definite advantages over other types of landholding. 17 Huch social and political content has been read into the language of these land conveyances and they have been intexpreted to collaborate a variety of theses-m fron the authenticity of the Matk 18 to the origin of the feudal systen in England.

The meaning of the writings of Caesar and of Tacitus which describe the landholding customs of the Germanic ancestors of the English is by no means clear. For example, Tacitus deals with the occupation of land in a passage frequently cited to support the theory of a free peasantxy. This passage is, however, engimatic and presents problems both of translation and of interpretation.

16 For exanples of these early charters see: J. Earle, A Hand-Book to the Land Charters, and Other Saxonic Documents (Oxford: Clarendon Fress, 1838), p. 2te.

17 Infra, pp. 26-27:

18 For an explanation of the Mark see infra, pp. $10 \mathrm{ff}$. 
Argi pro rumero cultorum an universis vicis occupantur quos mox Inter se secundum dirnationem partiuntur; facilitatem partiendi camporup spatia praestant. Arva per annos mutant, et superest ager. 19

Wuch of the controversy has centered around the words agri and ager, which have frequently been translated or interpreted to mean 'common lands', and held to exclude any concept of private property. This interpretation has been hotly contested by those who hold that a critical reading of the passage in context supports the opposing theory: the existence of servilc ratler than free communitics among the Germanic tribes observed by Tacitus, and ownexship of the land by a lord20

Perhaps the greatest single document illuminating the sociaI history of this period is Domesclay Book, compiled by Hilliam the Conqueror twenty years after his conguest of the English lands. Its purpose has been. disputed, its context the subject of frequent disagreement, but there is no doubt of its unique value. This comprehensive and massive survey of the conquered land and its peoples, their wealth, their status, reveals many things about the pre-existing Anglo-Saxon society that other records fail to show. 21 Its mastery,

19 "Land is taken up by the village as a whole, in quantity according to the number of the cultivators: they then distribute it among themselves on the basis of rank, such distribution being made easy by the extent of the donain occupied. They change the arable land yearly and there is still land to spare." Tacicus, Dialogus, Agricola, Germania, trans. H. Hutton (Cambridge, Mass.: Harvard University Press, 1963), p. 301

$$
20 \text { Infra, pp. } 20-21 \text {. }
$$

21 Haitland has said: "If. English history is to be understood the lav of Donesday Book must be mastered. We have here an absolutely unique account of feudalism in two different stages of growth," F. M. Maitland, Domesday Book and Beyond (London: Collins, 1969),p. 3 . 
however, is no easy task: any interpretation of the Domesday text presents difficulties steming both from the nature of the inquest and from the state of the records. 22 Moreover, its evidence must be intexpreted in the light of customs existing on both sides of the channel. The historian must decide what the questions asked by the inquisitors implied and what the answers of the conquered people meant. Norman concepts and Tioman idioms superimposed on AngloSaxon responses must be $t$ dentified; Noman classifications of English property rights must be carefully evaluated. Further, in bringing the evidence of Domesday Book to bear on earlier institutions history must be 'read backwards", always a precarious method of historical inquixy.

The problem of the origin of property in land and of the common man's status in eaxly times was by no means a new one in the 19 th century. It was stated and examined first by historians on the continent. Their theories and the conclusions they reached strongly affected the controversy among the English writers.

22see: V. H. Galbraith, the Making of Domesday Book. (Oxford: Clarendon Press, 1963); Sayles, pp. 289-90. 


\section{CHAPTER II.}

\section{THE PROBLIMI: FREEYAN OR SERF}

That theory which proclaims freedom as the condition of early Teutonic man is generally known to historians as the Mark theory. It is closely connected with one of the fundamental controversies of the history of Westem civilization: the question whether the influence of Roman culture continued after the break-up of the Empire, or whether the Cermanic txibes destroyed that culture and began the reconstruction of civilization from their own rude customs. Historical scholars in this area are usually labeled Romanists or Gemanists. The fomet tend to oppose the theory of the Mark and the latter to support it.

\section{THE EUROPEAN BACKGROUND}

The German Historians

German historians, in an effort to defend their ancestors against the charge of barbarism, leveled particularly by the French, tended to romanticjze primitive conditions among the Germanic peoples. The Nark theory in its earliest form appeared as a myth describing the beginnings of society as an idylilc period when mankind lived together in Eraternal communism. In 1768 the myth was put into historical form by Justus löser in his work Osnabrichische Geschichte. Móser saw the peasant of the old Saxony of pre-Carolingian times as 
a free man, cultivating a parcel of land which was his private prom perty (the lark). ${ }^{I}$ The various individual. homesteads in any given area were joined in an association by mutual consent of the property holders for social and political purposes. These units were known as Mark-associations (Markgenossenschaft). The associates (Markgenossen), in open meetings attended by all, directed the agricultural interests and acted as a governing body of the comunity. According to robser private property was the predominant form of ownership and communal usage extended only to that part of the land which could best be utilized in common-pasture, forest, and waste. ${ }^{2}$ Möser's romantic picture of the German free peasant was strengthened by legal writers in the early 1800s. Both karl von Savigny and Kari Frederich Eichnom refected the Roman notion of social and legal systems established in accordance with logicaily fomed ideas in favor of a theory holding that the Jaws and institutions of a people emerged gradually from custom and tradition. ${ }^{3}$ Going beyond róser's concept

1,ark was originally the Germanic word for 'boundary', but its meaning was extended to include the actual property or settlement which the boundary delineated.

"This summary of Möser's views is taken from: A.tfons Dopsch, The Economic and Social Foundations of European Civilization (London: K. Paul, Trench, Truber \& Co., 1937), pp. 5ff; and Carl Stephenson, "The Problem of the Common ian in Early Europe", Mediaeval Instjtutions, Selected Essays, ed. Bryce D. Lyon (Ithica, iv.Y.: Corne11 University Fress, 1967), pp. 262ff.

${ }^{3}$ On the position of Savigny, Eichhorn, and Jacob Grimm on Roman law and its relation to the comon law of Gemany see lajtland's introduction to Otto Gierke, Political. Theories of the Middle Ages, trans. F. W. Mattiand (Cambridge: University Press, 1968), pp. vii$x 1 v$. 
of a commity of free individual property holders, Eichhorn, in his Deutsch Statts-und Rechtsfeschichte, enunciated a theory of the Mark which held it to be essentially commity property. His book was widely circulated and eventually became the standard text on cerman 1aw. This led to the general acceptance of his version of the Mark theory as a comerstone of Germany's constitutional and legal history. 4 A number of other German historians perpetuated variations of joser's theory. K. A. Rogge in Uoer das Gerichtswesen der Germanen (1820) claimed the early varior peasants recognized no rule, but governed themselves complesely wiţhout interference. Jakob Grinm in Deutsche Rechtsalterthune: (1828) emphasized the existence of both comunal and private property as fundamental Germanic landholding customs. Genrg von Naurer, like Savigny and Eichhorn, naintained that the state was a creation of its own history. In his work Gechichte der Varkenverfassung in Deutschland (1846) he rejected the idea of: individually held property and asserted that early cultivation of the Iand was the effort of whole families and tribes, not of individuals. 5

Paul Roth and Otto von Gierke presented theories of Germanic origins which stressed the poljtical aspects of the Markgenossenschaft. Both relied on the concept of freedom of the conmon man as the basis of the German state. Koth asserted, "It is the equality of all freemen that forms the main basis of the German state." Authorities are

${ }^{4}$ Eichhorn's theory was fully developed in the 5 th edition of his work, which was published in 1843. Dopsch, p. 8.

5 Maurer's position will be discussed more fully in relation to the criticism of his work by Fustel de Coulanges, infra, pp. 19-21. 
chosen by the community and responsible to 1 t. "Everything is permeated by the principle of self-government." The state's foundation rested not upon the feudal relationship of lord and man, nor upon the dependence of the warrior on a chief, but rather upon a bond between freemen themselves. This iemocratic constitution gave way to monarchy not because of force or necessiry but by the free choice of the people. According to Gierke "the right of the associates was freedom, the conception of freedon and of folk-association coincided." He held that "each man was equally the co-representative, co-protector, and comdefender of the folk-peace and the folk-1aw; and among the Germans this folk-association took the place of the state. 7 He maintained that in general every political communty (Genossenschaft) originated as a liarkgenossenschaft. The political association was, he believed, of greater importance than the economic one. Thus the original picture which Moser sketched of men drawn together naturally, chiefly for economic purposes, has changed considerably. The Markgenossenschaft has now become an important political unit: the basis for the government, the constitution, and the law of the state. Economic historians approached the problem from a different viewpoint. Thoy vere interested in establishing facts concerning ancient agriculture rather than in the possible social and political

6P. Foth, Geschichte dos Beneficialwesens (1850), p. vii, quoted in Dopsch, Pp. 15-16.

70. Gierke, Das Deutsche Genossenschaftsrecht (1868), Vo1. I, p. 35, quoted in Dopsch, ए. 17.. 
significance of the field systems. Thus feorg Massen, George Landau, and August Mictzen, in works dating from 1835 to 1868 , brought a new dimension to the study of the condition of early Teutonic man. All of then, however, accepted some variation of the Mark ticory as the basis of many of their conclusions. Erwin vasse extended their methods to the study of English agrarian history. Tie, too, rejected tie notion of private property among the English peasants in favor of a commul agricultural enterprise. The cooperative venture was, however, essentially an economic one with few political and social implications. 8

Soveral German historians, as early as 1844 , began to question the political extension of the Marle theory. Georg Waitz was among these. One of the most outstanding of Leopold von Ranke's students, Waitz brought not stendards of historical scholarship to old problems. He insisted on careful analysis of sources and refused to give them greater significance than their wording justified. Thus he lield that "the view according to which the Hark-associations vere the basis of all political combination among the Germans must be abandoned" as an unhistorical generalization of Moser's theory, which was 1imited to Moser's own part of Germany.9 Such a conclusion, he contended was based on a superficial reading of Tacitus and Caesar. Even so, he accepted the Mark-association as "the basis institution of Gemanic

8. Nasse, Zur Geschichte der mitilalterlichen Feldgemeinschaft in England (1369), ciced in paul Vinogradoff, Villainage in England (Oxford: Clarendon Press, 1968), p. 26.

${ }^{9}$ C. Vaitz, Deutsche Vcrfassungsgeschichte: Vol. I. Nie zeit vor den grossen Wanderungen $(1844), p$. 31, quoted in Dopsch, p. 12 . 
society, an agrarian association that might well have political functions of a Iocal character." 10

Rudolf Sohm $^{11}$ and August liteitzen ${ }^{12}$ also attacked the extensions of Moser's original theory, but like Waitz neither of them rejected the basic assumption of an economic association of free peasants as the common form of early society. Rudolf von Greist, discussing the origins of Inglish institutions, stressed their aristocratic nature during the Saxon period. Even so, he admitted "the original personal freedom of the great mass of the people" and considered the "Inglish condition... one variation of Teutonic development."13.

In 1896 Werner Wittich, a pupil of the agrarian historian Georg Frederick Knapp, in an appendix to his work Dic Grundherrschaft in Nordwestdeutchland, advanced the argunent that the freenan described by Tacitus and Caesar was in reality not a peasant at all, but rather a small landlord. The majority of the men who tilled the soil in that early time were, he held, servile peasants working on the lands of landlords both great and small. This near heresy was vigorously

10 Stephenson, p. 264 .

${ }^{11_{R}}$. Sohm, Die altdeutsche Reichs-und Gerichtsverfassung (1871), cited in Dopsch, p. 18 .

12A. Heitzen, Der Boden und die landwirtschaftichen Verhaltnisse des preussischen Staates (1868), cited ibid.

$13_{R}$. Gneist, Gnglish Verfassungsgeschichte (1882). The quotation is Virrogradoff's, Villainage, p. 25. Greist spent much of his life studying English govemment; for an interesting analys is of his work sce: C. E. McCleIland, The Geman Historians and England (Cambridge: University Press, 1971), pp. 135-144. 
attacked by Heinrich Brunner and Pichard Schröder who again triumphantly asserted the theme of liberi homines: the common man was a free warrior pegsant until the disintegrating influences of feudalism set in. 14 As late as 191.8 Ruciolph Heuber, professor of legal history at the University of Giessen, in his work The History of Geimanic Private Law, assmed the early existence of the Mark, of the Mark association as a political unit, and of the Gay-Mark as a more extensive political unjt formed by a number of Mark associations. ${ }^{15}$ These assumptions are basjc to his discussion of "Juristic Persons and Other Associations" and "the Law of Land: Ormership."16

The theory of the Mark, in all of its forms, was based on evidence which could easily be the subject of more than one interprefation. Two factors appear to have been influential in its widespread acceptance in Germany: First, the romantic 'tum to nature' and the notion of the 'noble savage', inspired by the writings of: Jean Jacques Rousseau; and second, a great desire among Germans to reject the label 'uncultured barbarian' and the 'catastrophic theory' of the defeat of the Romans in Gaul which placed the Germans in the role of destroyers of civilization. Most German historians, unable to cast off the spell of the Mark theory, neglected to examine the

14 Yor a sumary of the positions of Brumer and Schroder see: Stephenson, pp. 268-69.

$150 n$ the origin and meaning of the term Gau see: Dopsch, pp. $167 \mathrm{ff}$.

${ }^{16} \mathrm{R}$. Hueber, 'The History of Germanic Private Law, trans. F. S. Philbrick (iTew York: Augustus H. KelIy, 1968), chs. III \& IV. 
evidence upon which its existence rested. This task fell largely to French historians, who eagerly welcomed it.

The French Historians

Early $19 \mathrm{th}$ century French historians did not, for the most part, deal directly with the Nark theory. Many of them were, however, confimed Romanists. Francois Guizot, in his Essais sur 1'histoire de France (1823), gave a picture of early Germanic society quite different from that presented by loser and the German historians who followed him. Guizot held that by the time the Germanic tribes had reached the Rhine their civilization had passed beyond its early phases of the free allod and individual freedom. The early Frank was a simple tenant farmer, comexisting peacefully with the great Ronan estate owner, ox occassionally entering into his service and fighting for him. ${ }^{17}$ Gradualiy the common mail was absorbed economically and politically into a system of territorial lordship.

Augustin thierry was a fixm upholder of the 'catastrophic theory' of the German invasions and held the Franks to be mere nomads, possessing no specific form of property in land. In his ConsideraEjons sur 1 'histoire de France (1827) and Recit des temps Merovigiens (1840) he advanced theses of the greatness of Gallo-Roman civilization

${ }^{17}$ Guizct defined the term 'Frank' as meaning a Germanic 'freeman'. He held that the Trankish confederation was composed of a number of tribes of these fxeemen, but that the names of the tribes vere not certain. F. Guizot, A popular History of France, trans. Robt. Black (6 vols.; Boston: Dana Fistes \& Charles E. Laureat, 1870), Vol. I, pp. 130-31. 
and of the racial superiority of the Gauls over all other peoples, especially the Franks. 18 Benjamin Guerard, writing in the first half of the century, investigated problems of the classes of men, types of land tenure and kinds of Institutions arising during the course of the Geman invasions. le rejected "the thesis that Gaul was civilized by Frankfsh invaders; he showed that... the manor as well as the administration were Roman institutions." 19

The first strong attack upon the Mark theory in jts basic form came from Numa Denis Fustel de Coulanges in his essay De Ia marche germanique. 20 Fustel was from the beginring a convinced Romanist. He was greatly influenced by the historical. writings of Guizot, and by the Cartesian metholodogy of doubt. 21 on every issue his thesis was clear: the German invasions of Gal in the sth century vere savage and barbaric, reducing to ruin the Roman civilization existing there, and leaving only chaos and confusion. The invaders brought

18Thierry turned cven his Histoire de la Conquête de 1'Angleterre par les Normans (1825) into a vehicle for his favorite theme: "the gradual rise of fallo-Roman civilization against the Teutonic conquest in France." vinogradofe, p. 16.

19. W. Thompson, A History of Historical Writing (2 vols.; New York: The Macmillan Co., 1942), Vol. II, P. 362 .

${ }^{20}$ This essay originally appeared in Fustel's Recherches sur quelque problcms d'histoire (1885). It has been published in English under the title The origin of Property in Land (1890).

$21_{\text {Fustej }}$ clained that from the tine of his introduction to Discours sur la methode he applied the Cartesian principle of doubt to all his vorks, Thompson, p. 363, fin. 9. 
with them nothing of value of their own in the vay of govemnent, institutions, or tradition, for they had nothing to bring. Any viable institutions which they had after setting down were, be contended, of koman origin.

Instead of arguing about the extension of Moser's early Mark theory as other historians had done, Fustel proposed to examine the beginnings of that theory. In the opening pages of his essay he states his purpose. It is not his intention to attack the theory of the Mark itself, but rather to examine the authorities upon wich 19 th century historians claim the theory rests.

The object of this cold and tedious procedure is not that of proving whether the theory is true or false; it is only to discover whether the authorities that have been quoted can be fairly regarded as appropriate. In short, I am going to discuss not the theory itself, but the garb of learning. in which it has been presented. 22

The primary target of Fuste1's attack was Georg von Maurer's Einleitung zur Geschichte der Mark-Hot-Dorf-und Stadverfassung (1854). Since the authorities quoted by Maurer to support his positions are those most commonly cited by other supporters of the Mark theory an examination of Fustel's findings is enlightening. Maurer had contended:

${ }^{22}$ Fustel de coulanges, The origin of Property in Land, trans. Nargaret Ashley (London: George Allen \& Unwin, 1927), p. 3 . 
Al1 land was in the boginning common-land, semeinland or allmende... There was nothing which could be rightly termed privatc property... The ground was divided into equal lots, and this division was made afresh each year; every member received a part and noved each year to a new lot... The whole mark, cultivated land as well as forests, vas held in common... The idea of property only came as the result of Roman law... Property, as we find it in later times, was produced by the decomposition of the ancient mark. 23

The earliest authorities upon which Maurer relied were Caesar and Tacitus. Fustel, upon examination of the passages to which Maurer referred, asserted that in no instance did the reference clearly support Naurer's contention. For example, Maurex translated the words agri and ager in chapter 26 of Germania to mean common 1 ands. 24 Fustel held there was no authority for such translation because the word 'common' was not to be found there at all. 25 He claimed rather that laurer had simply used the cranslation to support his preconception of tive sfark's reality. The word 'mark', he held, never meant anything more than the boundary of a territory or of a private estate, and this conclusion must be reached on a careful reading of Caesar and Tacitus. 26

In a similar fashion Fustel examined Maurer's claim that the German law codes supported his position. He found "that the mark was a district possessed in common by a number of persons there is

$$
\begin{aligned}
& 23 \text { Quoted in Fuste1, p. } 4 \text {. } \\
& 24 \text { Surra, pp. } 7-8 . \\
& 25_{\text {Fuste1, pp. } 5-10 .} \\
& 26 \text { Ibid., p. } 14 .
\end{aligned}
$$


not a trace in German 1aw."27 A check of the other documents upon which laurer relied yielded the sane result: neither the Traditiones 28 deeds, nor other land grants proved the existence of the commul Mark. Fustel then concluded:

The success of Maurer's theory is not to be attributed to the strength of his evidence... The book, nevertheless, has had enormous influence. It bas won many by its neat consistency, others by its apparent learning. Anything like verification of its argunents was gladly dispensed with. And so, year after year, for forty years, the same story has been repeated, the same argunents brought forward, the same authorities quoted. 29

In spite of the power of Fustel's argument th had little effect on the persistence of the doctrine of the liark anong scholars of his day. German historians remained as anxious as ever to defend the thesis of primitive commism as the precursor of private owership of Iand, wile even French historians fejt that fustel had gone too far. 30 It was in England, however, that the controversy was renewed most vigorous $1 y$, and from a somewhat different point of view.

\section{THE ENGLISH BACKGROUND}

In the early part of the 19 th century sone attempts were made to reconcile the Germanic and Romanist elements in English history. Sir Francis Palgrave, in $\triangle$ History of the English Commonwealth (1832), stressed the continuity of Roman influence among the Gennan kingdoms

27 Ibid.

${ }^{28}$ Classifications of charters of the 8 th to the 14 th centuries. 29 Juste1, pp. 61-62.

${ }^{30}$ Stephenson, pp. 265 ff. 
in England. He did not deny the Teutonic element in English social and political structures, but believed its importance had been greatly overemphasized. 31

The theory of the Mark was adopted by English historians almost without question, however, by the middle of the century. It fitted we11 with English ideals of freedom and democracy, and it supported the popular thesis of strong Germanic, rather than Roman, influence in the development of carly socicty and institutions. English social history, it was generally held, began with the settlement of Teutonic groups of independent freemen in village commities, either with common ownership of all the land or at least of the pasture, waste, and forest. The lord of the manor, according to this opinion, appeared at a later time, and through various legal and economic means depressed the free peasantry into serfdom, a process which was completed by the Norman conquerors. 32

John M. Kemble: The Saxons in England

John M. Kemble (1807-57), one of the first Englishmen to write a history of institutions, ${ }^{33}$ applied the Mark theory to English soil in his two volume work, The Saxons in England (1849). He had studied in Germany under Jacob Grimm and Andreas Schmeller, and was a thorough

${ }^{31}$ Vinogradoff, pp. 11-16.

32 William J. Asinley, Surveys, Historic and Economic (New York: Augustus 1. Ke11y, 1966), p. 39 .

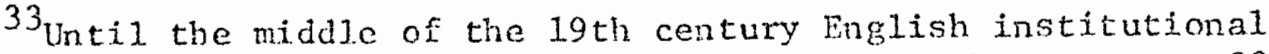
history was written largely by German historians. Thompson, p. 382 . 
Germanist, attributing Germanic origins to all important English institutions except the church.

For Kemble the rord Mark had two meanings: one designated a space of land, and the other a political unit. As a territory the Mark could be either the whole district occupled by a communty or in a restricted sense 'a boundary", that is "those forests and wastes by which the arable is enclosed, and which separate the possessions of one tribe from another." The arable land, which was portioned out to several members of the communty, was inseparable from the boundary land and "taken togethex clley nake up the whole territorial possession of the original comatio, kin or Exibe." 34 As a political association the Mark was composed of the freemen of the community Who, in this capacity, set out for themselves, and strictly maintained, a system of cultivation under which the produce of the land on which they settled wight be "fairly and equally secured for their service and support; and from participation in which they jealously excluded all who were not born or adopted into the association." Each Mark had its own court "and suit and service to such court was not less the duty, than the high privilege, of the free settlers." 35

The Marks in England, Kemble believed, were organized into Gás (corresponding to the German Gau), an ancient name later superceded by that of Scir or shire. These folloved the natural divisions of

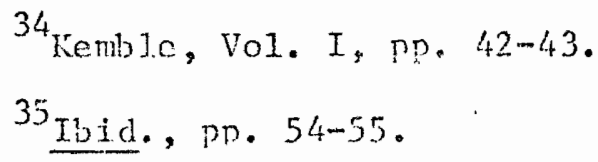


the country; cach had its administrators, judges, and priests, chosen from the elders of the Gá. It is probable that some of the modern shire-divisions are continuations of Gás which "have remained unchanged fron the carliest times." 36 Thus, the Marks, according to Kembje, fomed the basis of all social, economic, and political aspects of early English socicty.

Further, in kemble's eyes, personal freedon, landholding, and law were woven together in an inseparable manner. There vere two qualifications for the status of freeman. The first and most important was the possession of land.

Even as he who is not tree can, at first, hold no land vithin the limits of the community, so is he tho holds no land therein, not fully free, whatever his personal rank or character may be. 37

The landless, man was politically disenfranchiscd: he could not represent himself or his interests in the courts and assemblies; rather he was compelled to rely upon others for his economic livelihood and for security against his enemies-m." a necessary consequence of a state of society in which there is no property but 1and." 38 The second qualification for freedom was personal rank, which Kembie says "in the Teutonic scheme appears inseparably connected with the possession of 1and." 39 A man is born to that status, and can remain secure in his freedom as long as he is able to protect

$$
\begin{aligned}
& 36 \text { Ibid., pp. } 76-77 . \\
& 37 \text { Ibid., p. } 35 . \\
& 38 \text { Ibid., p. } 91 . \\
& 39 \text { Ibid., p. } 122 .
\end{aligned}
$$


his position, first tirough the strength of the family or clan, and later by law administered through the larger political unit, the Gá or the state. "For man is free through the existence, not the absence of $1 w^{\prime \prime}$ administered by the political association. 40

While there were unfree men, slaves and serfs, in early English society, Kemble appeared to regard unfree status as an aberration rather than the normal state for Teutonic man. These men had lost their freedom in a number of ways. Slavery was the result originally of "war and subsequent conquest" and of the "forfeiture of ljberty for crime." 41 There were two principal classes of serfs, natura and causa. The former were born to serfdom as children of unfree parents; the latter were reduced to their unfree status in various ways--by the fortunes of war, by marriage to a serf, by settlement anong serfs, by voluntary surrender to a master, by crime, by superior legal power, and by illegal power or injustice. 42 Anong serfs there were degrees of unfreedom, both legal and economic, but "the one fact still remains, viz. that he is in mund or hand of ancther, represented in the state by that other, and consequently, in the most emphatic sense of the word, unfree." 43

During the Anglo-Saxon period a marked loss of independence among the free peasants accompanied changes in the' manner in which land was held. Three types of landholding ivere common by the end

$$
\begin{aligned}
& 40 \text { Ibjd., p. } 130 . \\
& 41 \text { Ibid., p. } 186 \\
& 42 \text { Ibid. , pp. 194fí. } \\
& 43 \text { Ibid., p. } 189 .
\end{aligned}
$$


of the period: Folkland (fólcland), Bookland (bocland), and Loanland (laenland). All of these forms, according to kemble, had evolved from the original territorial iark.

When the land was first divided among the freenen there vere large amounts remaining in the hands of the community to be used commally, as the pasture, waste, and forest, or to be left untouched and reserved for future use. These lands cane to be known as folkland, terra publica, ager publicus. 44 thile the use (dominium utile) could be granted to individuals, the absolute ormership (dominum directum) remained in the state. Host of the grants, Kemble believed, were made only for the life of the grantee, and because the holders of such lands were "not included in the Narks" he concluded "it is impossible to beileve that their condition was one of such pexfect freedom as that of the original allodial owners." 145

Bookland resulted when land was granted by charter or 'book', and it normally came into being when the king made grants of land to. ecclesiastical organizations, or to individuals in reward for services to the state. Such grants could cone either from the comon land, or from lands privately held by families which for some reason had reverted to the state. Once land becane bookland it noxmally retained that character. It was an especially desixable form of landholding, for the 'book' not only provided evidence of ownership, but nade the

${ }^{4} 4$ The theory that folkland was communal. or public land vas widely held until it was demolished by vinogadoff, in his article "Folkland", Encrish Historical Review, VIII (January, 1893), pp. 1-17. 45 Kemble, pp. 292-93. 
land, from that time fonvar, heritable, alienable within limits of the originel grant, and exerpt from all public burdens except the trinoda necessitas. The great increase in landinolding by 'book" spelled disaster for the comon man.

... in consequence of this, there was no more room for the expansion of a free population, the condition of the freemen becalie depressed, wille the estates of the lords increased in number and extent. In this way the coorlas or free cultivators gradually vanished, yjelding to the ever growing force of the noble class, acceptine a dependent position upon their bócland, and standing to right in their courts instead of their ow old county genttas...

Loanland could be created by a lease of either folkland or bookland. If a holder of folkland leased his interest in the land to another the lease would necessarily expire on the death of the lessor, since he could grant no greacer right than he hinself pos-

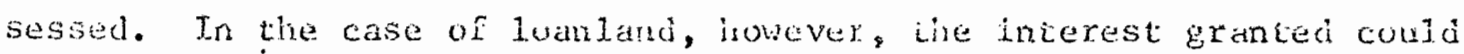
be of certain duration: a lease for the life of the grantee, for example, was not teminated by the death of the grantor, but remained enforceable against his heirs. Often in such cases the position of the tenant could be improved, the terns of his lease made more favorable, when he performed certain services for the landlord-lessor. These benefits were, however, illusory, for it is here particularly that kemble found origins of dependent tenure. He examined the services demanded of three types of peasants, the geneat, the cotset Ia, and the gebur, all ostensibly free men, and concluded that the duties ${ }^{46}$ Ibid. , pp. $326-307$ 
required were often heavy, sonetimes appearing to border on the burdens of serfiom. 47

The evidence upon which kemble relied for his beljef in the Mark were the passages fron Caesar and Tacitus ve have already mentioned, 48 as well as theories of Geman historians such as those of Eichhorn and Grinm. 49 That the Teutonic peoples who settled Britain brought with them the custons of their homeland he believed was selfevident. 50 He relied strongly on place names as proof of the continuity of the lark, and there is a long appendix to volume one of The Saxons in England purporting to relate the names of early liaxks to present day English local names. 51 while a number of references are made to Domesday Book, to Bede's Ecclesiastical History, and to AngloSaxon literature, the chief source matexial for Saxons in England is the early land charters. In them kemble found language and property descriptions which he used to support his statements. 52 He was the first historian to attemp verification and classification of this large mass of material and his Codex Diplomaticus Mevi Saxonici. . constitutes his grcatest contribution to historical research.

47 Ibid., pP. $310-26$.

${ }^{48}$ Supra, pp. $2,7-8$.

${ }^{49}$ Supra, p. 12. On Kenble's use of these authorities see Vinogradoff, Viliainage, p. 1.8.

50 "However far we may pursue our researches into the early records of our forefathers, we cannot discover a period at which this organization the Markl) was unknown." Kenble, p. 37.

51. Ibid. pp. 449-86.

52 For a different interpretation of early nngish society based on an examination of the land charters see: Farle, pp. xivi ff. 
The Saxons in England exemplifies Kemlide's basic assumption that the Teutonic invaders were frecmen in their homeland and that they established a similar free society in England. It implies that the history of England is simply a manifestation of Teutonic greatness. The evidence he presents fails to justify such sweeping conclusions.

\section{Henry Maine: Villoge Communities East and West}

Henry Sumner saine $(1822-83)$, one of the truly great figures in the bistory of early law and jurisprudence, was a Cambridge educated classical scholar. He was influenced by the tenets of the German historical school of law founded by Savigny, and by the Darwinian theory of evolution. He was among the fjust to use the comparative $C$ method in the study of laws and institutions, and his Ancient Law (1061) is said to have accomplisided for jurisprudence what Darwin:s Origin of the Species had achieved for biology. 53 He is acclaimed as the founder of England's historical school of law, which placed emphasis on law as a natural growth of the history of a nation rather than as a set of a priori concepts. His followers in this respect were some of England's most noted legal scholars: Paul Vinogradoff, Frederic Maitland, and Frederick Pollock.

In Village Communities in the East and West (1871), Maine seeks to shov that in the societies he is examining the development of law and institutions have followed a similar course. He found in the

53 H. S. Maine, Ancient Iav, Intro. C. K. Allen (London: Oxford University Press, 1931), p. ix. 
Indian village of his day a Jiving example of the institution of property which he believed existed in early medieval. Europe and in Anglo-Saxon England.

If very general language vere employed, the description of the Teutonic or Scandinavian village commuities might actually serve as a description of the same institution in India. 54

In each of these areas he found "the arable nark, divided into separate lots but cultivated according to minute custonary rules binding on al1" and the waste or common land out of which the areble mark had been cut "enjoyed as pasture by all the community pro indiviso." 55 Iaine accepted completely Maurer's thesis of the hark. The ancient Teutonic cultivating community, as it existed in Germany itself, appears to have been thus organized. It consisted of a number of families standing in a proprietaxy relation to a district divided into three parts. These three portions, wate the lark of the rownship or Village, the Common Maxk or maste, and the Arable Mark or cultivated area. The community inhabited the village, held the common mark in. mixed ownership, and culcivated the arable mark in lots appropriated to the several families. 56

In the German commities the original distribution of the arable area was, Maine believed, in exactly equal portions in accordance with the number of families in the village, and redistribution of these portions was made perlodically. The change from comnon to individual ownership occurred gradually and vas finally completed when "each family was confirmed for a perpetuity in the enjoyment of

${ }^{54} \mathrm{H}$. S. Maine, Vj.11age Communities in the East and West (London: John Marry, 1871), p. 107.

55 Ibid.

${ }^{56}$ Ibid., p. 78. 
its several. lots of land." 57

In England the same process was repeated: there vas no abrupt change from ancient forms of property to the feudal form; it was rather a gradual, almost imperceptible movement. Today, both in Gemany and in England, Naine claims vestiges of the old forms are to be found, not only of the comtion mark or waste, but also of the arable mark. The names which give evidence of these survivals in England are 'common' or 'open' fields, 'intermixed' lands, 'lot meaciows', and 'laminas lands'.

... I have been greatly surprised at the number of instances of abnomal proprietary rights, necessarily implying the former existence of collective ownership and joint cultivation, which comparatively brief enquiry has brought to my notice. 58

Maine's style of writing was expository rather than argunentative or technical, and he onitted the numerous citations that nomally accompany a historical or legal work. He has been criticized chiefly for his broad generalizations, unsupported by specific evidence, concerning the development of early societies and laws. His acceptance of the Mark theory places him in the mainstream of English historical writing of his day.

The Oxford Schoo1

H11ian Stubbs. The Oxford school of historians of the 19 th century is said to have begun with Villiam Stubbs (1825-1901), who assumed the Chair of Yodern History at Oxford in 1866, the first

$$
\begin{aligned}
& 57 \text { Ibid. pp. } 81-32 . \\
& 58 \text { Ibid. } \\
& \text { p. p8. }
\end{aligned}
$$


trained historian to hold the post. ${ }^{59}$ His arrival. heralded a new era in English historiography narked by more systematic methods and by the tenet that history was to be studied for its own sake, using all materials availabje. His greatest work vas Ihe Constitutional Ilistory of England, published between the years 1874 and 1878. Primarily a history of institutions, it covers the church, the state, law, justice, administration and finance fron the time of Julius Caesar to the accession of the Tudors. Stubbs' conservativism, his belief in tradition and gradual change, is reflected in the opening, sentences of the preface.

The llistory of Institutions cannot be mastered, - can scarcely be approached, - vithout an effort... But it has a deep vaiue and an abiding interest to those who have courage to work upon it. It presents, in every branch, a regularly developed series of causes and consequinces, and abounds in examples of that continuity of life, the realization of which is necessary to give the reader a personal hold on the past and a right judgment of the present. For the roots of the present lie deep in the past, and nothing in the past is dead to the man who would learn how the present comes to be what it is. 60

A logical consequence of beliefs such as these was Stubbs' firm acceptance of the existence of the lark among the Germans and among the early English. He relies upon the works of German historians as well as upon the ancient authority of Caesar and Tacitus. He claims traces of the lark can still be found in the Salian 1aw. 61

59 On the Oxford school see: G. P. Gooch, History and Historians in the Nineteerth Century (London: Longmans, Green \& Co., 1952), pp. 317 f.

60 Villian Stubbs, The Constitutional History of England (3 vols.; Oxford: Clarendon Press, $1374-78$ ), Vol. I, p. ii.t.

$61_{\text {Ibid. }}, p p .58 \mathrm{ff}$. 
of all his English predecessors he admired Kenble most and referred to him as his "pattern scholar." 62

Stubbs held that duting the Tettonic invarsions many of the Britons were killed, and many others wore pushed back into the highlands of Scotland, into Vales, and to Ireland. Among those who remained few vestiges of Roman influence were to be found, for the Celts never intermised to any great extent with the Romans-meir cultures had for the most part remained separate. 63 The invading Saxons themselves were "a pure nationality, unconquered by the franks, untainted by Roman manners, and sti11 neathen. "64 Thus Stubbs held that the Gemanic institution of propericy was transferred to England relatively free of any Roman influence.

Stubbs agreed with kemble in holding that the beginnings of property in land in the Germanic system was a communal form, but he belfeved that by the boginning of the Anglomsaxon period commul lands were being divided into two types: land still held by the state for the benefit of the community at large, and land owned separately by individuals. Private land was efther an ethel, that inherited or acquired by original allotment, or an estate created out of the common or public land. The term alod was one properly applicable to both types of private lands. These two forms, public

${ }^{62}$ Goochs s p. 320 .

63 Stubbs, p. 65.

64Ibid., n. 64; for a discussion of the Germanic tribes in England and were they settled see: D. B. Hardin (ed.), Dark Age Britain (London: Methuen \& Co., 1956), pp. 21-122. 
and private property, became later the folkland and the bookland described by Kemble. 65

Near the end of the Anglo-Saxon period a trend developed toward the consolidation of lands, and a consequence of this trend was the prevalence of frecmen holding in dependent tenure (loanland). When the Nomans made the Donesday survey it was difficult for them to grasp the variations in Anglomsaxon tenures: freemen were holding land by various leascs; unfxee men tre working on the same estates, both classes of men Erequently were performing duties that appeared to be identical. The conquerors tended to interpret the Anglo-Saxon system in the light of the customs of the Norman manor with which they were familar. The result was often a luming together of all peasants engaged in sinilar tasks under the heading 'vi11ein'. 66 Stubbs asserted that the political association, Mark, could have been the foundation of the early English township, for he believed traces of that system were still inexistence. He felt, however, it was more probable that the Teutonic settlers had passed beyond the stage of the lark-association when they migrated to England. On this point he disagreed with Kemble. 67

It is as an owner of land, or as a fully qualified 'lawful $\operatorname{man}^{\prime}$, not as a menber of the mark community, that the freeman has rights and duties, and there is no evidence that in England the only way of owning land was the membership of the nark.

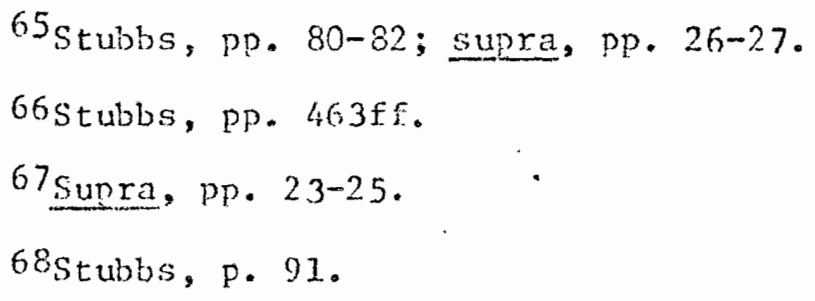


Although Stubbs' version of the Mark theory is a more conservative one than Kemble's, it js he who has borne the severest cricicism for accepting that theory without firmer proof of the Mark's actual existence. This is probably because stubbs was the better known historian, reputed in most of his work to be a careful, thorough investigator. Others have felt the harshness of the criticism leveled at him is unjustified. 69

Edward A. Freenan. Two other members of the Oxford school were also supporters of the theory of Germanic orjgins of English property concepts. Both of these were friends and adnirers of Stubbs, although in many ways the three were very unalike. Edward A. Freeman (1823-92) is remembered principally for $\mathrm{h}$ is monumental six volume rork, The History of the Norman Conguest of Jng and $(1867 \cdots 79)$. He followod Stubbe as Regis Professor of History at Oxford in 1884, when the latter resigned to become Bishop of Chester. Freeman was a militant radical, an extrovert, with. a flamboyant style and a blustering personality. He presented a strong contrast to the conservative Stubbs with his careful, concise style and his methodical research techniques? 70

Freeman added little that was new to the development of the Mark theory. He relied for authority chiefly on Kenble's and Stubbs' interpretations, though he also cited Caesar, Tacitus, Eichhorn, Waitz, and Maine, anong others. The earliest glimpse of Teutonic

69 "It has been the work of a later generation to exhibit the complexity of Anglo-Saxon socicey, and he camot be seriously blamed for failing to anticipate their researches." Gooch, p. 320.

70 1bid., pp. 323-29. 
political life showed, he asserted, the existence of monarchic, aristocratic, and democratic elemonts. The last was the most important for the "ultimate sovereignty" resided in "a free and axmed people." 71 The primitive Teutonic commity "occupies its own territory, its Haxk." Its lands "consist of both common land and individual land which is assigned by common consent." Alongside this "primitive democracy" there existed the Comitacus described by Tacjtus, that is, "the personal following of the chiefs." These were the men who eventually composed the aristocratic class. 73

Freeman followed stubbs in holding that lomesday Book provided evidence of remants of pre-feudal land tenure, and that it revealed substantial. encroachments on the common man's freedom made long before the Norman Conquest. This reduction of freedon occurred cliterly through loss of lanis with resulting comendation, and by the loss of jurisdiction. Lithe: Stubbs, also, Freeman sat Noman misinterpretation of the consequences of comendation under AngloSaxon custom as a prine factor hastening the loss of freedom after the Conquest. Similarly, lands held in common were regarded by the Normans as an aberration foreign to the feudal system, and therefore merely a revocable right granted by the large landowner to his agricultural workers. 74

Although he was a brilliant man of wide leaming Freeman has

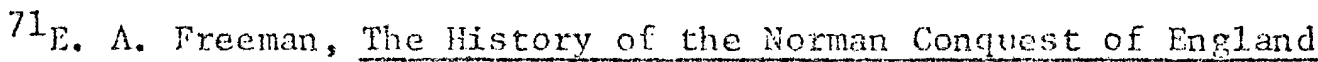
( 6 vols.; Oxford: Clarendon Press, 1877-79), Vol. I, pp. 80-81.

72 Ibid., p. 84.

73 Ibid., p. 86 .

74 Ibid., Vol. V, pp. 462-63. 
not been considered a distirguished historian, chiefly because he refused to do research outside his own library. He "vas ignorant of palaeography"; he had a "strange aversion to the employment of manuscript authorjties" and "an insuperable repugnance to working with archival material." 75 Under such circumstances it is not surprising that he simply parroted versions of the Mark theory which had appeared in the works of others.

John Richard Green. The youngest of the Oxford trio and the most original thinker, John Richard Green (1837m83), might have become another Gibbon. or lacaulay had he survived to fulfill his potential. His fane rests, hovever, primaxily on one book, A Short History of the Bnglish People (1874), which he later enlarged to four volumes. The work vas unlilo most histories of the era in that it presented in summary a story of the people rather than of war and politics, and it was an inmediate success. It became a textbook for schools, and undoubtedly spread the theory of English beginnings in freedom more widely than had any other work.

Green's picture of the early Teutonic freeman was as idyllic as that of Hoser more than a century earlier.: "In their villages lay ready formed the social and political life which is round us in England today." In early Anglo-Saxon socjety the eor].'s superior position "rested simply on the free recognition of his fellow villagers. Within the township cvery freeman or ceorl was equal. It was the freeman who was the base of village society." Land and public $75_{\text {Thompson, }}$. 317. 
justice were "everythere the accompaniment of full freedom." The plough land alone was allotted to individuals while the remainder of the land was held in comon. It was the "sharing in the common land" that set apart the freemen from the unfree. 76 As did scubbs and Frceman, Green found the common man's loss of freedom a gradual process, begun ve11 before the Conquest through consolidation of properties and commendation, and completed as the result of the Conquest.

As authorities for his position Green cites the works of Kemble and Stubbs among others. His position was closer to that of Kemble than Stubbs, however, for he too was a thorough Germanist.

Wis worst error was the notion of an jidyllic primitive democracy among the old English, and the fallacy that popular representation has alvays been the essence of the English constitution's growth. 'Green's story of linglish origins is based... upon a legend... The nineteenth century crowds in upon the sixti. $: 77$

These historians, from kemble through Green, so different in many respects, fell under the spell of the Nark theory primarily for the same reasons: a strong predisposition to uphold the doctrines of English beginning in freedom, and reliance on the works of the German historians. The next group of men we shall consider were neither so unquestioning in their methods, nor so fjrm in their belief in the innate goodness of the prinitive Teuton and his institutions.

76 J. R. Green, A Short History of the Inglish People (New York: Harper \& Brothers, 1833), pp. 7-12.

$77_{\text {Thompson, p. } 321}$ 
CHAPTER III

THE HISTORLANS: JEGAL ART ECOIOUIC

Frederic Seebohm (1833-1912) was the first. Finglish historian to oppose directly the tcnets of the Cermanist historians. It was he who challenged those great medievalists of the period, Paul Vinogradoff (1854-1025) and Frederic Wj11ian Maitland (1859-1906), to defend the concept of the free man in early England. Seebohm's position was strongly supported by Wilijam Ashley (1360-1927), an ardent adnirer of Fustel de Coulanges, and a critic of Vinogradoff and Maitland.

None of these men accepted the Mark theory as it had been sot forth by Maurex and propagated in England by Kemble and his followers. Although no two of them were in complete agreement on all of the issues involved, for the most part Vinogradoff and Maitland, often labeled Germanists, opposed the position of Seebolm and Ashley, usually classified Romanists. The labels are an oversimplification, for the debate among these scholars shows the positions they assumed were the result of a number of factors.

\section{FREDERIC SEEBOHM}

Frederic Seebohm was an amateur historian, and by profession a banker. His father, an evangelical Quaker, had come to England from Germany in 1814 and settled in Bradford there Frederic was born in 
1833. Young Frederic received his early education at Bootham, the Friends' school in York. Pecause the family had little money it was decided he should read for the bar. It was for this purpose that he moved to Hitchin and commuted to London where he entered the chambers of an attoney. At Hitchin he met and married a local girl of considerable weath and social position, and eventually became a junior partner in his father-in-law's bank. 1 .

Seeboin was a devout Qualier and throughout his life he worked for various educational and charjtable projects. During this period, when politics and social divisions were apt to be based on religion, he fitted the usual pattern. As a Quaker he was a supporter of Gladstone and tho Liberals; he presided at the meetings of the llitcinin Radical Association, and vas syn pathetic to the cause of the laboring man. In 1884 he prepared to run as a parliamentary candidate for one of the Hertfordishre divisions on the platform of reform in the interest of labor. He was, however, forced to withdraw his candidacy when his partners at the bank decided that they could not spare him the necessary time away from his duties. He was deeply disappointed and frustrated by this rude end to his political anbitions. ${ }^{2}$

In spite of the lack of a broad educational background Seebohm had serious academic interests. Mane's lectures had stimulated him to study history, and the vritings of Colet, Erasmus, and More

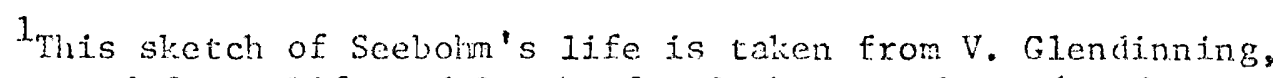
A Suppressed Crv: Life and Deach of a nuaker Daugliter (London: Rout ledge \& Kegan Paul, 1969).

${ }^{2}$ Ibid., pp. 4n-41. 
influenced his intellectual outlook. His early works, The oxford Refomers (1867) and The Era of the Protestant Revolution (1874), reflect his strong religious beliefs, his moralistic attitudes, and his smypathy for the comon man. It was, however, a series of works on economic agrarian history that established seebohm's reputation as a historian and gave him a degrec of lasting fame: The English Village Commity (1883), The Tribal System in Wales (1895), Iribal. Custons in Anrio-Saxon Law (1902), and Customary Acres (1914).

Of these the most important work, as well as the most controversial, is The English Village Conmunity. In the preface Seebohm states his purpose:

It is simply an attempt to set English Economic History upon right lines at its historical commencement by trying to solve the sill open question winther it began with the freedon or with the serfidom of the masses of the people - whether the village communities living in the 'hams' and 'tons' [sic] of England were, at the outset of English history, free village communities or comunities in serfdom under a manorial. lordship...3

Such an econonic inquiry will, he believes, enable him to find "secure stepping stones over what may be impassable gulfs in constitutional history," for the continuity of the evidence of economic history may prove to be better preserved than that of constitutional history. Thus a purely economic inquiry may "prove that more things went into the 'making of England' than were imported in the keels of the English invaders of Britain. 14

${ }^{3}$ F. Seebohm, The English Village Comunity (Port Washington, N. Y. London: Kenniliat Press, 1883), p. ix.

${ }^{4}$ Ibid., pp. xivixv. 
Seebohm also sets out the method of investigation he intends to follow. He will examine the "cast-off she11 of the English village conmunity," that is, the system of conmon or open fields, the remains of which still survive in parishes "where no Enclasure Act happens to have swept them away. ${ }^{5}$ One of these survivals is in Hitchin where "men are still living who have held and worked farms under its inconvenient rules, and who know the meaning of its terms and eccentric details." 6 He will then proceed from this known and certain evidence-this shell. that can be clearly secn, whose distinctive marks and traits are easily fdentiffable-1"to trace back the shell by searching and watching for its mark and traits as far into the past as evidence can be found." In this manner, seebohm believes, an añwer to the question of the status of the comon man at the beginning of the English perjod can be found.

Using the knowledge so acquired about the shell as the key, the inquiry will curn upon its occupant. Examining how the mediaeval. English village conmunity in serfdom fitted itself into the shell, and then again working back from the known to the unknown, it may be possible to discern whether, within historical times, it once had been free, or whether its serfdon was as oli as its she11.

Seebohn's exposition begins with an examinatton of the modern remains of the open fields of Hitchin Manor, which he holds is a

$$
\begin{aligned}
& { }^{5} \text { Ibid., p: xiii. } \\
& { }^{6} \text { Ibid., p. xiv. } \\
& { }^{7 \text { Ibid. }} \\
& { }^{8} \text { Ibid., p. xiv. }
\end{aligned}
$$


good example of the open field system once prevalent throughout England. As late as 1816 maps show that the arable land was divided into long strips of approxinacely equal size by balks of unploughed turf, and was cultivated nomally by a three-field crop rotation. These fields were in recent times, as the manorial records show, those belonging to a village community which functioned under a manorial lordship. 9

The normal holding of the man who worked the land, the villanus was a 'yard-Jand' or 'virgate.' This was not a term of measurement, but described the bundle of land strips held by an individual worker. The number and size of these strips was determined by the work of the plough, and the yardland of the average villein presupposed ownership of two oxen in the 'common plough of eight oxen.' In order that each member of the plough tean might sow his land shortly after it was ploughed, a day's work was divided among them (except for strips allocated to the lord or the church). Thus the division of land among cultivators was not based on a notion of equality between free men, but rather on a communal pattern of land sharing among serfs. 10 The fact that the strips remained equal in size, and were not subdivided furthex, as they would have been had they been heritable, substantiated this conclusion. ${ }^{11}$

$$
\begin{aligned}
& { }^{9} \text { Ibid., pp. 1-16. } \\
& { }^{10} \text { Ibid., pp. } 22 f f . \\
& 11_{\text {Ibid., }} \text { p. } 177 .
\end{aligned}
$$


Seebohm finds that this same system, "the shell of serfom-the manor with a village community in villenage upon it" can be traced back to the time of the Domesday survey through the evidence of the manorial and hundred roJls, and the contemporary work Fleta. ${ }^{12}$ Domesday Book itself shows clearly the existence of a servile peasantry working the manorial land. The survey reveals the existence of 108,407 villani, holding an average of twenty acres of land: 82,000 bordarif (cottagers), holding about five acres each; and 6,000 to 7,000 cottler tenants, holding a fev scattered strips in open fields. All of these vere servile tenants holding in villenage. In the Danelaw about 23,000 sochmanni $^{13}$ held approximately half a million acres, and 12,000 liberi homines may have held another half million. About five million acres vere in cultivation throughout England under the manorial system which forned the economic base of the country.

12 Fleta is an anonymous work, compiled during the reign of Edward I, designed to give landlords the legal knowledge necessary for the management of their estates and courts. Ibid., p. 45.

${ }^{13}$ Apparently Seebohm is referring here to 'free socmen,' who held their land by a tenure closely related to free tenure. The services by which they held were apt to be somewhat heavier than those exacted of the liberi homines. However, their personal status is classiffed as 'free' and not'servile.' These men were found throughout England, but in greater numbers in the Danelaw. The other group of socmen vere those holding by 'villein socage,' a priviledged, but still a base tenure in that they were excluded from the king's courts and liable for the 'work-week.' The villein socmen were found chiefly on the Ancient Demense of the Crown. Lipson, Economic History, pp. 51.-54. 
This was the economic condition in which England was left by the Sazons as the result of the 500 years of cheir rule. The agriculture of England, as they left it, was carried on under the open field system by village communities in villenage. It vas under the systen of Saxon serfdom... that the land was tilled throughout all those counties which the Saxons had thoroughly conquered, with some partial exception as regards the Danish districts 14 where the sochnanni and liberi homines were settled.

The evidence of the Anglo-Saxon period bears out this conclusion. The Rectitudines Singularun Personarum, which probably dates from the loth century, describes the sexvices due from the thane to the king and from the tenants in villeinage to the thane, and shows, Seebohm holds, the extstence of a servile conmunity. 15 An examination of other Saxonic documents fails to reveal the existence of the free village commity at any time. Thus the evidence of trie earliest Saxon or Juidsit laws supports the view that the Saxon har or tun was the estate of: a lord, and not of a free village community, "and that it was so when the laws of the Kentish men vere first codjfted a fer years after the mission of St. Augustine."16

When Seebohm reaches that critical period of English history, the 'dark ages' of pre-Saxon times, he examines continental evidence in an effort to determine the relationship between the Roman provincial land system, the German tribal system, and the manorial

${ }^{14}$ Seebohm, pp. 103-104.

15 Seebohn says the Rectitudines Singularum Personarum ('the services due from various persons') "night be the very model from which the form of the Domesday Survey was taken." Ibid., p. 134. 16 Ibid.s p. 175 . 
system of England. 17 The results of this investigation lead him to conclude that in England the open field system in its simpler form predated the Roman conquest and at the same time showed many of the characteristics of the Roman villa. He can discover no evidence of the three-field system either in wales, proving that it was not common among the Celts, or in north Germany, showing that the Saxon invaders did not bring it with them. On the other hand be finds it to be most prevalent in those areas on the continent known to have been under Roman influence. 18

Sechohm concluded that the influence of the Saxons on the English agricultural system had not been so great as had theretofore been held; he suggested that the invaders might have come from middie Germany, known to have been under Roman frfiluence, as well as from the north. The existence of the open three-field system (the 'she11 of. serfdom') could be explained satisfactorily only by assuming that the Germanic tribes took over that system, which they found already in existence in Britain, and modified it to suit their own needs and limitation. The ease with which they did this presupposes familiarity with such a system in their own country.

It is most probable that whenever German conquerors descended upon an already peopled country where agriculture vas carried on as it was in Britain, their comparatively small numbers, and still further their dislike of agrieultural pursuits and

17 Ibid. pp. $252-411$.

18 Here Seebohm relies on the works of German scholars Landau, Hassen, and Meitzen. Ibid., pp. 371-74, 410. 
liking for lordship, and familiarity with servile tenants in the old country, would induce then to place the conquered people. in the position of serss, as the Germans of Jacitus seem to have done, making then do the agriculture by customary methods. 19

Thus he denied those interpretations given by earlier historians to the writings of Tacitus: what Tacitus saw in Germany, in all probability, was not villages of freemen led by a chieftan, but servile communties clustered on lands belonging to an overlord.

In The English Village Community Seebolm placed the theory of early English freedon in jeopardy in a number of ways. He denied that Tacitus' Gexnanja offered any proof of a free community landholding system, wich might have been transferied by invaders to England. He found no authority in the Anglo-Saxon laws to support the assertion of freedom. He refused to recognize Donesday book as a source revealing vestiges of freedom or as giving any supportive evidence to that theory. He identified serfdom with the patrern of land cultivation which predominated in England. This was his most devastating blow; while earlier historians had given social and political implications to the crazy-quilt designs of the open flelds Seebohm saw there only the work of the plough.

Strangely enough the early Mark historians had paved the way for Seebohm's position. The theory of the German hark, no matter what the ultimate verdict upon tis existence, was of great service "as a vorking hypothesis by means of which the study of the economic problem has ${ }^{19}$ Ibid., pp. 418-19. 
been materially advanced." Thus Seebohm expressed his indebtedness to Maurer, Kemble, Maine, and Stubbs. 20 More specifically, however, he relled upon the studies made by Landau, Hanssen, and Meitzen of the open field system found in Germany. 21 Fustel's work, The Origin of Property in land, hat no influence upon Seebohm, for although it was written earlier than The English Village Community it was not published until 1835. Thus neither Fustel nor Seebohn was aware of the conclusions of the other.

Seebohm vas influenced by, and in turn exerted influence upon, contemporary historians working on the same problem, and in the same field. Rmong these were Denman Ross of Harvard University, and John Earle of Oxford. Ross, in a work entitled The Early History of Landholding anong the Germans (1883), held that the change in German life from pastoral to agricultural was effected by means of siavery. Accompanying this transtion "a class of dependent freemen or clients was coming into existence almost everywhere." 22 This class and the slaves gradually merged to form one large class of serfs which comprised the bulk of the population in western. Europe during the early Middle Ages. In Tacitus' time the majority of so-called freemen were in effect serfs. While in theory these men might be politically free, they were economically bound to the land. ${ }^{23}$ Ross believed that private

$$
\begin{aligned}
& 20 \text { Ibid., p. xixi. } \\
& 21 \text { Ibid., p. xii. } \\
& 22 \text {. Ross, The Early History of Land-holding among the Germans }
\end{aligned}
$$
(Boston: Soule \& Bugbee, 1883), P. 3 .

$$
23 \text { Ibid., p. } 128 .
$$


ownership of land preceded comon holdings, and further, that the existence of common holdings was no proof of primitive communism. 24 Earle, in the lengthy introduction to Land Charters and Other Saxonic Jocuments (1888), disagreed with Kemble's interpretation of the early Anglo-saxon land charters, and held they provided no evidence for the existence of the Mark. ${ }^{25}$ Earle held that before Secboh's work appeared there were fwo principal. theories of the origin of manorial rights. These have been called the 'legal theory', espoused by Blackstone, and the 'historical theory', established by "economic and historic enquiries."

According to the legal theory, the lord of the manor is the absolute owner of the soil, and whatever rights or benefits the conmunity. may enjoy, they ore to his concession and clemency. According to the historical theory, on the contrary, the Manor is a degenerate transformation of the Free comburity, through the aggraiditement and usuppod powers of one of its menbers: the Fremen of the town. ship having sunk dow into the Villeins of the Manor.

Earle held that Seebohm tied these two theories together by asserting that "the Saxon invader found in Britain a system of agriculture which is the true antecedent of the manor." In this position "the legal theory triumphs...not to the exclusion of the historical theory, but rather by its subordination and absorption." For while the original type is "the Roman vilua with its gang of slaves," from this has been developed the manorial system through "the wise and

$$
24 \text { Ibid., pp. } 63 \mathrm{ff} \text {. }
$$

$25 \mathrm{~J}$. Earle, A Hand-Book to the Land Charters and Other Saxonic Documents (Oxford: Clarendon Press, 1888), pp. xlvff.

$$
26 \text { Ibid.s p. Jviii. }
$$


humiane policy of the lords. 127

Seebohm's critics have accused him of oversimplifying an extremeIy complicated subject and of being too selective in the evidence he used. Specifically these criticisms have been voiced: First, he failed to account for the free propxietors who were admittedly a neccssary part of the manor. Wot all of the Germanic host could have become proprietary landloris, for there were too many of them. ${ }^{28}$ Second, he did not take into account vardations in the field systems found In England, but seemed to assune that the open three-field system prevailed everywhere. ${ }^{29}$ Third, his assumption that English villages grew on Roman villa sites was erroneous, as archaelogical finds have proved. ${ }^{30}$ Finally, he gave no adequate explanation for the existence of the communal slement in the early manorial system.

In spite of these criticisus most historians have agreed that the interpretation Seebohm advanced was long overdue and have acclaimed hin as a pioneer in the field of economic agrarian history.

$$
\begin{aligned}
& 27_{\text {Ibid. }} \text { p. xil. } \\
& 28_{\text {Ibid. , p. } 1 x .}
\end{aligned}
$$

${ }^{29}$ For newer interpretations of the open field system see: $\mathrm{H}$. Gray, Inglish Field Systems (Cambridge, Mass.: Harvard University Press, 1959); C. Orwin \& C. Orwin, The Open Fields (Oxford: Clarendon Press, 1967); H. Finberg (ed.), The Agrarian History of Bngland and Wales, A. D. 43-1042 (Cambridge: University Press, 1972).

30 The accumulated archaeological evidence of the last seventyfive years shows that in all probability the Romen villa did not survive into Anglo-Saxon England. Loyn, pp. I6ff.

$31_{W}$. J. Ashley, "The English Manor," introduction to Fustel de Coulanges, The Origin of Property in Tand, p. xliz. 
His work set off a flurry of scholarly research almed at bolstering the original thesis of the free common man, while at the same time taking into account the new economic point of view.

\section{PAUL VINOGRADOFE}

Dospltae Britaniae Gratus Advena

One of Seebohn's most distinguished challengers was a Russian by biuth, a medievalist, a legal historian, and a brilliant, accomplished scholar. Paul Gavrilovitch Vinogradoff was born on November 18, 1854, in Kostroma, Russia, the son of orthodox, conservative, middle class parents. His father was a teacher and a school director--a civil servant of some distinction. His mother was an intelligent and pexceptive woman, who early sensed her son's unusual gifts and encouraged him to develop then. Vinogradoff entered public day school at the age of thirteen and began to read prodigiously, particularly the works of western writers: Macaulay, Ihering, Michelet, De Tocqueville, and Louis Blanc. He completed his early schooling with distinction and was admitted to the Faculty of History and Philosophy at the University of Moscow in 1871.32

Vinogradoff's interest in the social and economic history of the middle ages was the result of seminars, modeled on the German plan, given by Professor Guerriex at the University. The works of

${ }^{32}$ This sketch of Vinogradoff's life is taken from H. A. L. Fisher, "Paul Vinogradofe, a Hemoir," The Collected papers of Paul Vinogradoff, ed. H. A. L. Fisher (2 vols.; Oxford: Clarendon Press, 1928), Vol. I, pp. 3-74. 
Ranke and de Tocqueville impressed upon him the necessity for detailed and methodical research.

$\Lambda$ brilliant thesis on landed property during the age of the Merovingians won him the gold medal and was the first earnest of his success in the field in which he was destined to win a worldwide reputation. 33

After receiving his Kussian degree he was awarded a scholarship for graduate work at the University of Berlin where he came under the influence of Theodore Mommsen and Heinrich Brwner. At the end of a summer spent in Bonn studying Greek history under A. Schaefer, Vinogradoff recurned to Moscow to begin his career as a university lecturet.

He was twenty-two years of age and already had given evidence of two great qualities-man encyclopaedic out look upon the field of law and histgry, and a capacity for minute antiquarian scholarship. 3

In 1873 Vinogradoff obtained leave from his teaching duties to prepare his master's thests. He was convinced that the answers to a great many questions of medieval social history could be found only through a better understanding of feudal origins and chose Italy as the place to carry out his investigations. His disscrtation upon the feudal origins of Lombard Italy was well received and firmly established his reputation as a notable medieval scholar. In the same year that Seebohm's English Village Community was published (1883), Vinogiadoff made another journey, this time to England, to gather materials on the English peasant and early agrarian practices. This

$$
\begin{aligned}
& 33_{\text {Ibid., p. } 11 .} \\
& 34_{\text {Ibid., p. } 12} .
\end{aligned}
$$


work was the basis of his doctoral thesis, and the ciegree awarded him by the University of Moscow. In 1892 the work appeared in English under the title Villainage in Fngland.

Vinogradoff's early reading had awakened his political consciousness and made him aware of the gross inadequacies of the government of Imperial Russia. His boyhood experiences had inpressed upon him the injustice of the deep class distinctions existing there and aroused his sympathy for the peasants and the servants whom he saw constantly mistreated. 35 At the University of Moscow as a student he found a liberal atmosphere "which offered a strong contrast to the education which went on in the clerical schools and colleges, and to the political repression of an absolutist government." 36

..As a young man, Vinogradoff felt the momentum of the 'glorious generation of the sixties,' which enancipated the serfs, created local self-government, regulated the lav courts, witnessed the birth of an independent press, and the reconstitution of the Universities as selfgoverning bodies. 37

This movement, he feIt, was not due to the influence of the Slavophils, who advocated that Russia look only to her own physical and intellectual resources for her development, but to the influence of the liberal western nations. His travels and his studies abroad had reinforced this opinion: he was thoroughly imbued with liberal ideas.

Vinogradoff was convinced that Russia could solve her internal problcms only through westernization of her systems of government and

35 Ibid. , pp. $6-7$

${ }^{36}$ Ibid., p. 9.

37 Ibid. 
education. The achievement of self-government was of primaxy importance, it was the basis "on which all other problems might be approached and solved." To reach the goal of self-government popular education of the loner classes was essential. ${ }^{38}$ He particularly adriced Englard's constitutional monarchy and hex "successful combination of order with liberty... and the all-prevading rule of law." 39 He believed that Russia would in time follow the English example and establish a parliamentary government to safeguard the civil liberties of the people. 40

To implement his beliefs, in addition to his reaching and research, Vinogradoff worked hard for governmental and educational reform. He was a member of the Moscow Municipal Duma and chairman of its education commites. He wrote textbooks for use in the elementary schools. He was a leader in the movement to free the universities from state control. As a constitutional liberal he wanted to see orderly change, and to this end he supported the Zemstvo organization and the Octobrist moverent. He had a deep faith in the abilities of the Russian people and was confident that in the end the path of reason would be followed. All of his life he was to be torn between his loyalty to his homeland and his frustration in the face of her repressive institucions. 41

38 Paul. Vinogradoff, Self-Government in Russta (London: Constable \& Co., 1915), pp. 4, 76 .

$$
\begin{aligned}
& { }^{39} \text { Elsher, pp. 9-10. } \\
& 40 \text { Ibid., p. } 10 . \\
& 41_{\text {Ibid., pp. } 24 f f .}
\end{aligned}
$$


As a full. professor at the University of Moscow, Vinogradoff was particularly anxious to see the Russian universities free of the supervision of state agents. The professors vere not only spied upon, but vere required to subnit reports to the police on the activities of their students. As Chairman of a Professorial Comittee Vinogradoff attempted to arrange a modus vivendi between the students and the Universjey authorities. ${ }^{42}$ His p1an was submitted to the Curator of the University and the Minister of Public Education; it was summarily rejected. Because of this blunt rebuff and the increasingly repressive atmosphere of the University, Vinogradoff felt he could no longer work effectively there, and at the end of the term, In 1903, he submitted his resignation. He was at the height of his career and popularity; his action created a furor among the students and uneasiness in the administration. In spite of this the authorities refused to reconsider any of the proposed reforms. 43

Faced with this unbending attitude vinogradoff, a proud and sensitive man, took his family and left Russia. In the spring of 1903 he arrived in England where he was velcomed by a group of distinguished men who were his warm friends and admirers. It was due to their influence and recomendation, as well as to his own high qualifications, that in the fall he was elected to the Corpus chair of

\section{Ibid., P. 28.}

43 Ibid., p. 29 ; see also The letters of Frederic Wijlitim Maitland, ed. C. H. S. Fifoot (Cambridge, Mass: Howard UnIversity Press, 1965), letter nos 373. 
Juxisprudence at oxford. The chair had been created for six Henry Maine and election to it, unusuel for a foreigrex, was a high academic honor.

He continued to hope that Russia rould take the middle road, and returned there frequently, eventually lecturing again at the University of Moscow during part of the year. But when it became clear that the revolutionary tide could not be stemed, he turned his back on his native country, and in 1918 became a British citizen. "It is not too much to say that the Russian Revolution broke his heart. ${ }^{1 / 4}$ Although he had great admiration and respect for England, and in turn received honor and acclain there--in 1917 he was knighted by the king, Vinogradoff remained a deeply patriotic Russian who had left his county because life for him there had becone imossible.

In the early days of the war his Slavonic patriotism biazed high...From a sensitive and intelifible pride he did not cate to be intexrogated about the ultimate misfortune of his country... So much humillation after so many bright hopes... 'It is the rule of the Anti-Chxist' he would say briefly and turn...the conversation elsewhere. 45

Vinogradoff was a true cosmopolitan: he spoke twelve languages and was completely at home in six of them. Many of his writings appeared in German, French, Norse, and Italian, as well as in English and his native Russian. His lectures and his historical investigations took him throughout Europe, to America, to India, and everywhere he was at home--his vast knowledge and his outgoing personality broke all cultural boundaries. "In the midst of a numerous and choice

$$
\begin{aligned}
& 44 \text { Fisher, p. } 59 . \\
& 45 \text { Ibid., p. } 74 .
\end{aligned}
$$


company he had the appearance of a prince." 46 It is no wonder that from the time of his first stay in England he was received into the inner circle of scholars and mon of letters. Among his friends and close acquaintances were the intellectual elite of the day: Albert Dicey, W. R. Anson, Henry Pelham, Sir Frederick Pollock, Sir Leslie Stephen, Sir Henry Maine, E. A. Freeman, Frederic Seebohm, and Frederic Maitiand.

Several of these men were working in the same field as that covered by Villaingre in England, and Vinogradoff had the opportunity to exchange views with then during the time his work was in preparation. A correspondence with Seebohm shows that while Vinogradoff had great respect for him as an 'original and brilliant investigator', he disagreed with many of his conclusions. He did not believe that the picture of early agriculture seebohn presented necessarily demanded the conclusion that the English peasant was a serf.

\section{Villainage in England}

Vinogradoff's writings fall into two main categories: those concerned with the origins and development of English social and legal history, and those concerned with jurisprudence or legal theory. The book for which he is chiefly remembered, Villainage in England, belongs to the first group and is generally considered to be his most brilliant work. It comprises two lengthy essays: "The Peasant of the Feudal Age," and "The Nanor and the Village Community."

$$
{ }^{46} \text { Ibid., p. } 48
$$


In "The Peasant of the Feudal Age" the status of the early English peasant is examined from two points of view: that presented by laws and legal writings, and that shown by the manorial records. The legal evidence is important not only because "it puts things into order and shape," but because lawyers and legal writers constantly struggle to analyze complex cases into constitutive elements and to bring these elenents under definite principles.

There is no law... which does not exhibit on its logical surface seams and scars, testifying to the incomplete fusing together or doctrines that cannot be brought under the cover of one principle. And so a dialectic examination of legal forms which makes manifest the contradictions and confused notions they contain actually helps us to an insight into the historical stratification of ideas and facts, a stratification which cannot be abolished however much lawyers may crave for unity and logic. 47

Although legal writers in the 13 th and 14th centuries tried very hard to build a law of villeinage on the Roman doctrine of slavery Vinogradoff finds "their fabric gives way at every point." The law of villeinage cannot be constructed by equating the position of the villein with that of the Roman slave, or of the freeman, or of the colonatus or ascriptus. "It contains elements from each of these three conditions, and it must be explained historically." 48 Thus in tracing the development of villeinage through court records and legal writings, Vinogradoff finds what he believes to be vestiges or survivals of freedom, incicating that in an earlier time the bulk of English peasants were not serfs but were free.

$$
\begin{aligned}
& 47 \text { Vinogradoff, Villainage, pp. 127-28. } \\
& 48 \text { Ibid., pp. 128-29. }
\end{aligned}
$$


Xf we remove those strata of the law of villainage which ove their origin to the action of the feudal system and to the action of the state, which rises on the ruins of the feudal system, we come upon remants of the pre-feudal condition. They are by no means few or unimportant, and it is rathex a wonder that so much should be preserved notwithstanding the systematic work of conquest, feudalism, and State. 49

The manorial records supplement and verify the evidence presented by the legal documents. Among the most important are the rolls of the manorial courts: these form "the stepping stones between local arrangements and the general theories of common law." It was here also that the rights and disabilities of the villein were most often pleaded, for the villein had no status in the comon law courts and the unfree tenure by which he held his land received no recognirfion there.

In addition to the manorial rolls, various other records give important information concerning the actual conditions under which the villeins lived and worked. These include the manorial 'extents' (descriptions of the adminisictation and operation of the manor) and royal inquiries based upon them, treatises on farming, instructions to manorial officers, and accounts of expenditures and receipts. These records show there existed a variety of customs which were followed by the different manors. For the most part, however, some uniformity is apparent. "The varieties naturally fall into certain classes and converge towards a few definite positions." 50 Such evidence, according to Vinogradoss, is somewhat more important

$$
\begin{aligned}
& 49 \text { Ibid., pp. } 133-34 . \\
& 50 \text { Ibid., p. } 139 .
\end{aligned}
$$


than legal rules, for these usiform custons "were not produced by artificial arrangenent from above," but were produced organically from the actual opcration of manors throughout England. 51

A careful analysis of the Domesday survey shows, in Vinogradof:'s opinion, that at that cime the bulk of the peasantry was not considered unfree. An assumption of original lfbexty is the only basis upon which much of the Domesday materdal can be explained. For one thing, the survey distinguished becween serfs and villeins, and notes only a small number of the former. This distinction is corroborated during the Norman period by laws which treat the villein in the same manner as the ceorl of Saxon times: he is deemed 'worthy of his were and of his wite'-the mark of a free man. 52 He was sometimes allowed to piead in the courts against his lord: where he had been deprived of his wayrage (his plough and plough team), 53 and occasionally on the ground of a covenant between himself and his lord. 54 Further the vilieln was called to the hundred court as a free man, even though he was not the holder of a free tenement. 55

Anothex indication of eariy freedom was the protection given the vaxious types of base tenure: ancient demense, villein socage, and gravelkind in kent. These cenures in practice escaped the rigid classification of legal theory as Eree or unfree, and as a consequence

5IIbid.

52Ibid., p. 66 .

53 rbid., P. 74 .

54 Ibid., pp. $70 f f$.

55 Ibid., pp. $188 \mathrm{ff}$. 
were subject to special rules. 56 Finally, a strong presumption of freedom prevailed in the law of this early period. The only proof which was accepted as conclusive evidence of villeinage was "absolute proof that the kinsfolk of the person claimed were villains by descent." 57 In all other cases the courts made every effort to find the peasant a free man; his liberty was always assumed until conclusive proof was brought against that assumption. This open attitude of the courts is not only evidence of "enlightened views, "but also evidence of an "original element of freedom" which "had been attracted into the constitution of villainage and was influencing its legal development despite any general theory of servile character. $" 58$

Vinorradoff concludes that, on the basis of the legal and manorial evidence of the feudal age," the general classification of society under the two heads of freeholders and villains is an artificial and a late one." 59 A third classification is necessary, that of 'customary freeholders', who were denied access to the royal courts, yet whose status showed 'vestiges of freedom', and whose rights in the land were guarded by the custom of the manor. These were the predecessors of the copyhoider, who eventually was embraced by royal justice and granted a means of protecting his interest in

$$
\begin{aligned}
& { }^{56} \text { Ibid., p. } 218 . \\
& 57 \text { Ibid., p. } 83 . \\
& 58 \text { Ibid., p. } 85 . \\
& { }^{59} \text { Ibid., p. } 220 .
\end{aligned}
$$


in the land superior to those available to freeholders.

...the feudal notion of a freehold from which the modern notion has developed must be supplemented from the point of view of the historian by a more ancient form which is hidden...inside the class distinction of Villainage. By the side of the freeholder recognized by later law there stands the villain as the customary frecholder who has lost legal protection. 60

Only by the supposition of this 'third estate' can "the ambiguous position of the feudal villain" be clarified. 61

In his second essay, "The Manor and the Village Community," Vinogradoff examines the manor as a social and economic unit, relying chiefly upon manorial records; cartularies, and the Domesday survey as source materials. At the head of the manor is the lord, and under him are two layers of population--the freeholders and the villeins. The land which the nanor occupies is divided into demense land, cultivated for the benefit of the lord, and the peasant holdings. The administrative busjness of the manor is carrjed out by the manorial officers or servants, who also supervise the agricultural labor and collect the rents. The peasant population lives in the village community, and the lord nearby in the manor house surrounded by its own grounds. The center of the community is the nanorial court or Halimote, which is both a tribunal and a council. 62

Vinogradoff examines in detail each of the facets of manorial life, particularly the open field system and the cultivation of the land by means of internixed strips. While seebohm had insisted on

$$
\begin{aligned}
& { }^{60} \text { Ibid. } \\
& 61_{\text {Ibid. }} \\
& 62_{\text {Ibid., pp. } 223-24 .}
\end{aligned}
$$


the prevalence of the three-field system, Vinogradoff finds that both the two and three-field systens were common. He agrees with Seebohm in holding that "the size and distribution of the holdings are connected with the number of oxen necessary for the tillage, and its relation to the full plough. 163 Thus the hide is the ploughland with eight oxen, the virgate is that requiring one yoke, or two oxen, and the bovate a single head. However, he opposes Seebohm's contention that the practice of alloting to each of the cultivators his holding or yardland in intermixed strips originates in the joint use of the plougin. Seebohm had argued that the strips into which the land was ploughed were divided among the men who fumished the oxen and the plough, in an order of predetermined succession on the basis of each day's work. The yardland of the average villein presupposed ownership of two oxen in the 'common plough of eight oxen. 64

Vinogradoff objects to this explanation on several grounds. First, the intermixing of strips is a "universal feature" which cannot be connected with such a "special instrument" as the eightoxen plough. In central Russia, for example, stifp intermixing is common though the tilling there is normally done with only one horse. Second, large land holdings of a hide or more, if Seebohm's explanation is to be followed, would be cultivated in one block, and not intermixed. Third, this line of reasoning would lead to the conclusion that the holder of a virgate, which was the normal holding of a

$$
\begin{aligned}
& 63 \text { Ibid., p. } 252 . \\
& 64 \text { Supra, p. } 43 .
\end{aligned}
$$


villein, always "stood In confunction with a sequence of three other tenants." 65 The facts, Vinogradoff says, do not support this inference. Final1y:

The observation that the peasantry are comonly provided with small ploughs draw by four beasts ruins Seebohn's hypothesis entirely. One vould have to suppose that most fields were divided into two parts, as the majority of the tenements are yardlands with half a team. 66

Vinogradoff is certain that the distribution of the land in intemixed strips could only have been due to the desire to establish an equality among the peasants "as to the quantity and quality of the land assigned to them in spite of all differences in the shape, the position, and the value of the soil." 67 The system was not an efficient method of cultivation and would nevex have been maintained on the basis of practicality alone. It reveals xathen "the Eramework of a peasant communty that has swerved from the path of its oxiginal development. "68 It is a stage in the development of landholding customs-from communal to private property.

Vinogradoff's examination of the manorial system leads him to the same general conclusion he reached from his study of the peasant: "survivals" point to "a more ancient order of things," quite incompatible with manorial husbandxy-man earlier free village communtty. Among these, in addition to the open fields themselves, are the rights

$$
\begin{aligned}
& { }^{65} \text { Vinogradoff, p. } 252 . \\
& 66 \text { Ibid. p. } 254 . \\
& 67 \text { Ibid. } \\
& 68 \text { Ibid., p. } 403 .
\end{aligned}
$$


of comnon usage of the pasture, the meadow, and the waste. "These... carry us back to practices which must have originally applied to arable also." 69 In the farm-system, that is, the practice of supplying the manor with food as rent in lieu of services, another vestige of former freedom can be found. For tenure based on food rent, which later developed into money rent, is not servile tenure, but free socage. Further the existence of free socage and servile tenure side by side "is a strong argment for the belief that free socage must not be considered merely as an emancipated servile tenure." 70 In a like manner the existence of free vixgates mixed with servile ones indicates "that in many cases the shares of the conmunity were originally distributed among free people who had nothing or little to do wth manorial worle."7l Finally, in the xequirement that freehold tenants are a necessary part of a manor if it is to be recognized as a legal unit with its own court, Vinogradoff sees unistakable evidence of original freedom. ${ }^{72}$ All of these survivals indicate that "the manorial element is superimposed on the communal and not the foundation of it." 73

Villainage in England was well received at the time of its publication, and was described as both brilliant and erudite. Its

$$
\begin{aligned}
& 69 \text { Ibid., p. } 404 . \\
& 70_{\text {Ibid. }}, p \cdot 311 . \\
& { }^{71_{\text {Ibid. }}} \text { p. } 352 \\
& 72_{\text {Ibid., pp. } 385 \mathrm{ff}} \\
& 73_{\text {Ibid. }} \text { p. } 408 .
\end{aligned}
$$


conclusion was one most English scholars were anxious to confirm, particularly after having been "somewhat rudely shaken from... Iiberal dogmatism by $F$. Seebohm's brilliant but paradoxical contention that English freedom was rooted in Roman slavery. "74 Later writers have praised Villatnage for its careful description and analysis of manorial life and institutions in the 13 th and 14 th centuries. Many of these writers have contended, however, that Vinogradoff's interpretation of the anomalies he found as survivals of a former state of freedom is farfetched, based on a preconception rather than on firm evidence. 75 Vinogradoff wrote two other books designed to supplement Villainage in England. In The Growth of the Manor (1904) he endeavored to sum up and harmonize writings of Seebohm, Round, Ashley, Maitland, and others on the legal and cconomic aspects of the manor. This was a necessary task, he felt, because "the manor is the master key to the understanding of medieval England... It is the Medieval analogue corresponding to the ancient civttas." 76 English Society in the Eleventh Century (1908), a commentary on the Domesday survey, is a detalled and complicated work, directed to the specialist rather than to the general reader. In the second essay, "Land and People," Vinogradoff reemphasized his hypothesis of the free element in early English society and stressed his contention that "the problem of the social origins of England camot be solved unless that element is

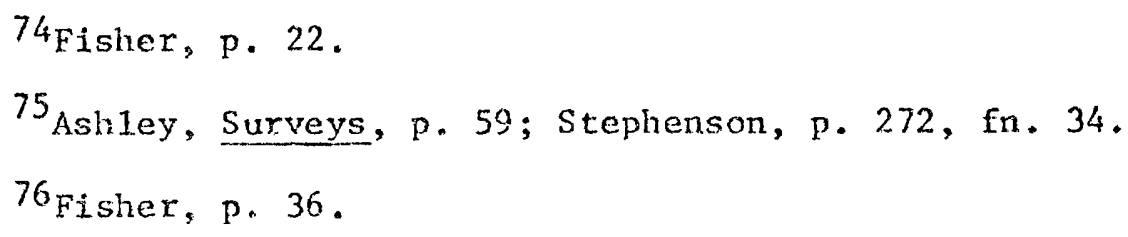


given due weight."17

Vinogradoff's later years were devoted to the first two volumes of what was to be a comprehensive survey of comparative law, entitled Outlines of Historical Jurisprudence. His untimely death prevented its completion. He was the author of many other shorter books and articles. Among these two must be mentioned: Roman Law in Medieval Europe (1909) is still the main work in English on the influence of Roman law in the Middle Ages. The short article "Folkland," published in the English Historical Review, January, 1893, completely demolished the widely held theory. that Anglo-Saxon folkland was communal or public land. Vinogradoff showed it to be, instead, family or inheritable land held other than by book or loan.

\section{FREDERIC MAITLAND}

The man who held Vinogradoff's highest regard, both as a scholar and as a personal friend, was Frederic William Maitland. Their friendship began in the early part of 1884 during Vinogradoff's first visit to England, and their close association continued until Maitland's death in 1906. They had much in common--both were legal scholars, historians, and medievalists; they became invaluable to each other as supporters and as critics. It was Maitland who read the English version of Villainage as it was being written, who criticized its contents and smoothed out Vinogradoff's then somewhat rough

\footnotetext{
77 . Vinogradoff, English Society in the Eleventh Century (Oxford: Clarendon Press, 1908), p. 479.
} 
English; 78 and it was Maitland who pushed hardest to secure for Vinogradoff a teaching position in England. 79 On basic questions they were generally in agreement, though their opinions differed on many lesser issues.

Maitland was born in 1850 into a family of lawyers and scholars. The names of his father and both his grandfathers appear in the British 'hall of fame,' The Dictionary of National Biography. 80 Like his father and paternal grandfather before him, Maitland attended Trinity College, Cambridge, was called to the Bar, and practiced law for several years. He specialized in conveyancing, a highly technical branch of 1aw; and this training stood him in good stead when, as a historian in later years, he found it necessary to interpret early English land deeds and charters as source matcrial.

The writings of Savigny and Stubbs had interested Mattland in legal history while he was still a student, and he soon perceived that he had a 'historical' rather than a 'legal' mind. A conversation with Vinogradoff on one of Leslie Stephen's 'Sunday tramps' about the 'treasures awaiting examination in the Public Record Office' strengthened Maitland's determination to abandon the practice of law for

${ }^{78}$ Fisher, p. 20; Maitland, Letters, nos. 56, 62.

${ }^{79}$ In 1895 when Vinogradoff first made inquiries about a position in England, Maitland wrote his brother-in-1aw H. A. L. Fisher: "I wish to heaven that I were prime minister at this moment! I would risk a war to put $P$. V. in the vacant chair." (The reference was to a vacant chair in Modern History at Cambridge, which Vinogradoff did not secure.) Maitland, Letters, no. 149.

80 The material used here is taken largely from C. H. S. Fifoot, Frederick William Maitland, a Life (Cambridge, Mass.: Harvard University Press, 1971). 
historical study. ${ }^{81}$ It was a decision he never regretted for it enabled him to develop his unique abilities to their fullest. He became a Reader of English Law at Cambridge in 1884, and was advanced to Downing Professor of the Laws of England in 1888. This was the position he held for the rest of his 1ife. From 1898 until his death, poor health necessitated his spending part of every year in the Canary Islands in order to avoid the cold, damp English winters. There he continued his writing, returning each summer to Cambridge to fulfill his professorial duties.

By nature Maitland was a kind, diffident man. He was. genuinely interested in others working in his field, anxious to encourage budding historians, and slow to criticize less capable writers, believing that the man and his pride were always more important than a deserved, but hurtful comment. On the other hand, he was a severe judge of his own work and received the critical comments of others with an objectivity rarely found among writers. 82 his ability "to formulate the right questions" and his "gossamer prose" made him an institutional historian without peer; obtuse and complicated subject matter became clear under his light touch. Sir. Frederick Pollock once said, "Maitland commanded the dry bones to live, and henceforth they are alive." 83 Above all Maitland insisted on 'historical-mindedness.' 84 For him the history of law was the history of ideas, and in this area particularly the

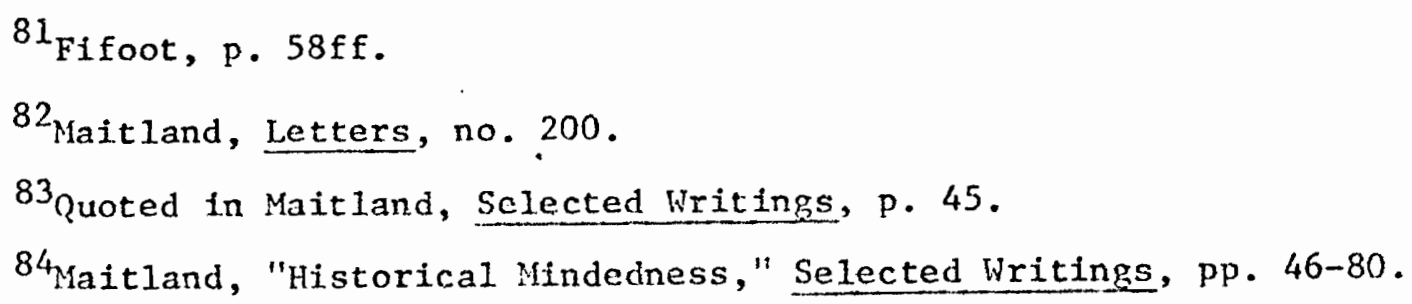


historian must use extraordinary care to avoid anachronism.

Everywhere the investigator finds himself compelled to deal with ideas which are not the ideas of modern times. These he has painfully to reconstruct, and he cannot do so without calling in question much of the traditional learning. 85

When the short span of time Maitland had to devote to historical studies is considered the amount and the quality of his vork seems not only remarkable, but incredible. His name appeared for the first time in the literary search room of the Record offlce in February, 1884, and his first inportant work, pleas of the Crown for the County of Gloucester, was finished in August of that year. Between that date and 1906 he published a number of books, many important articles, book reviews, and other writings. In addition he edited a number of manuscripts, including eight of the twenty-one publications of the Seldon Society, of which he was a founder. At the same time he was fulfilling his duties as a Professor of Law at Cambridge.

Among his many works only a few can be mentioned here. Essays such as thie "Introduction to Memoranda de Parliamento" (1893), "Township and Borough" (1897), "Ownership in the 01d English Community" (1898), and those on the persona ficta (1899-1903) led to small historical revolutions in the areas with which they dealt. Some of his best known books are Bracton's Note Book (1887); his definitive work, The History of English Law before the Time of Edward I (1895), coauthored with Frederick Pollock, though Maitland wrote almost all of its two large volumes; Domesday Book and Beyond (1897); Roman Cannon

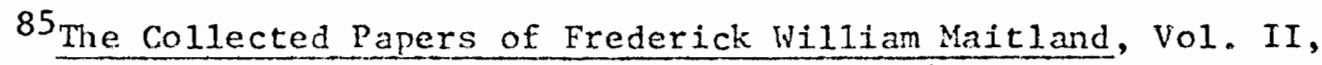
p. 8, quoted in Maitland, Selected Writings, p. 34. 
Law in the Church of England (1898); and the Life and Letters of Leslie Stephen (1906).

Many of the conclusions Maitland reached regarding early English history have been proved wrong by later historians. The measure of his greatness was not so much in making new discoveries as in opening up new fields and pointing the way to later historians. Thus some of the theories he advanced in Domesclay Book and Beyond have been discarded by modern investigators, but nonetheless it remains one of the great fundamental books of English history. 86 It is in this book that he most clearly advocated the Germanist point of view of original English freedom. In the preface he admits the work is a partial. answer to Seebohm's thesis, and expresses the hope that he will receive further support from Vinogradoff in the form of a sequel to Villainage. With a characteristic light touch he adds:

When that sequel comes...my provisional answer can be forgotten. One who by a few strokes of his pen has deprived the English nation of its land, its folk-land, owes us some reparation. 87

Before the writing of Domesday Book and Beyond Maitland had declared his position as a Germanist and with the publication of The History of English Law his rejection of the idea of any strong Roman influence on English institutions was clear. There he pointed out that the Roman element in English law had come not before the Teutonic

${ }^{86} \mathrm{H} . \mathrm{E}$. Bel1, Maitland (Cambridge, Mass.: Harvard University Press, 1965), pp. 32-33.

${ }^{87} \mathrm{~F}$. W. Maitland, Domesday Book and Beyond, pp. 5-6. See supra, p. 67. 
invasions, but much later with the establishment of the Roman church in the late 6 th century.

There is no trace of the laws and jurisprudence of imperial Rome, as distinct from the precepts and traditions of the Roman church, in the earliest Anglo-Saxon documents. Whatever is Roman in them is ecclesiastical. 88

That the church itself had to make a new conquest of England is clearly established. In the light of this discontinuity of Roman influence on the church Maitland was convinced it was even less like1y that civil institutions survived the invasions.

It is difficult to believe that civil institutions remained continuous in a country where the discontinuity of ecclesiastical affairs is so pointedly marked, and in an age when the Church was far more stable and compact than any civil institution whatever. 89

The greater part of Dornesday Book and Beyond was written to be included in The llistory of English Law, but for several reasons it was not. 90 Thus much of the material is legally oriented, although its main concern is with social history in general. Maitland uses Seebohm's method of investigation, that of proceeding backwards from the more plentiful materials of English history in the 12 th and 13th centuries to the earlier periods. His starting point is Domesday Book, and from there he goes to the laws and charters of the Saxon period, which are, in his opinion, the only materials available to illustrate five hundred years of legal history.

${ }^{88}$ F. M. Pollock and F. W. Maitlind, The History of English Law Before the Time of Edward I (2 vols.;. 2nd ed.; Cambridge: University Press, 1952), Vo1. I, p. xxxil.

${ }^{89}$ Ibid.

9011aitland, Domesday Book, p. 5 . 
The book is composed of three essays. In the first, "Domesday Book," Maitland examines and analyzes the survey itself. One of his conclusions is that the book was primarily a geld or tax book, rather than a register of title, a feodary, a custumal, or a rent rol1. 91 In this opinion he was supported by the contemporary historian John Horace Round, and their thesis was generally accepted for almost fifty years. More recent studies, however, present fairly conclusive evidence that this interpretation was erroneous, as was its corollary that "a manor is a house against which a geld is charged." 92

In the second essay, "England before the Conquest," Maitland develops his thesis of a free peasantry. It is his view that the manorial system was not fully developed in England until after the Norman Conquest. Prior to that time free peasants were in the majorIty, though there were several classes with different degrees of freedom, holding land by various kinds of tenure. He traces the gradual suppression of the peasants, beginning in the Anglo-Saxon period: by the creation of bookland and loanland, by the loss of folkland, by the grant of sake and soke to lords by the king, by the growing poverty of the peasant and his consequent commendation to a lord. This suppression, he finds, was accelerated by the Norman conquerors.

\section{${ }^{91}$ Ibid., p. 25 .}

${ }^{92} \mathrm{~V}$. H. Galbraith, The Making of Domesday Book (Oxford: Clarendon Press, 1963); R. W. Finn, The Domesday Inquest and the Making of the Domesday Book (Lond on: Longmans, 1961). 
Maitland refuses to accept the theory that the English manor can be traced back to the Roman villa and he questions Seebohm's use of much of his evidence. 93 The Saxons, in his opinion, invaded England in numbers too large to enable them all to become substitute Roman landlords over a subservient Celtic population. Further, "the English language and the names of our English villages are the unanswered protest" against such a theory. 94 He rejects arguments advanced by Seebohm based on the evidence of the open fields that servile conditions predominated. Without going into the technicalities of early agriculture he asserts that the open fields were not Celtic nor Roman in origin, but were "purely and typically German."95 He feels that the economic historians have not been able to present any logical argument based on field patterns. He adds a humorous comment:

I cannot but think that Fustel de Coulanges knew his business thoroughly well, and that if the German is to be taught his proper and insignificant place, the less that is said of intermixed 'strip-holding' the better, though to ignoxe it utterly was, even in France, a bold course. 96

It was Maitland's contention that the free village community was agrarian and not political: that it had no assembly or court,

${ }^{93}$ For example, Maitland holds that the Rectitudines Singularum Personarum (see supra, p. 45, fn. 15) may not be much older than the Norman Conquest, and further that it reveals clearly that a variety of free classes existed at that time. Domesday Book, pp. $383 \mathrm{ff}$.

94 Maitland, Domesday Book, p. 266.

95 Maitland cites Meitzen in support of this statement, whereas Seebohm cites him for the opposing position. Supra, p. 46, fn. 18 . For an evaluation of lieitzen's work see Dopsch, pp. 111ff.

96 Mait land, Domesday Book, p. 395, fn. 1. 
and no legal entity. 97 He disagreed with those historians, including Vinogradoff, who asserted that the earliest form of property was community property. He rejected both the notion of a primitive corporate body of freemen as owners of the land, and the idea of the state as owner.

No one who has paid any attention to the history of law is likely to maintain with a grave face that the ownership of land was attributed to fictitious persons before it was attributed to men. 98

The evidence rather points to co-ownership of the land by members of the community. Co-ownership, however, is not community ownership; it is instead ownership by a number of individuals of an undivided interest in a common piece of land. The meadows, the pasture, the waste were, in his opinion, held in this fashion both anong the Germans and in early. England. In making historical judgments of this kind it is important, Maltland points out, to consider carefully the mentality of early man.

The task of reconstructing ancient ideas is hazardous, and can only be accomplished little by little...If, for example, we introduce the 'persona ficta' too soon, we shall be doing worse than if we armed Hengest and Horsa with machine guns or pictgured the Venerable Bede correcting proofs for the press.

The third essay, "The Hide," is an attempt to define that important and ever-illusive term, so essential to the interpretation of English medieval documents. Maitland choses the large hide of

97 On this point Maitland was clearly in the minority.

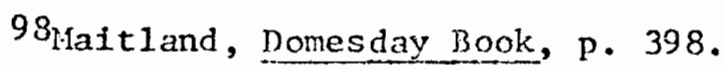

${ }^{99}$ Ibid., P. 415. 
120 acres as his preference. This choice is important to his thesis of the movement of the peasantry from freedom to serfdom, for such a large holding would rarely belong to a serf or semi-servile colonus. 100 Almost immediately this definition of the hide was questioned and it has never been widely accepted. ${ }^{101}$

In spite of the attacks upon Domesday Book and Beyond, of ten made with weapons which Maitland himself furnished, its basic importance remained unchallenged; nor did support for its central theme-the freedom of the early peasantry--diminish. Sir Frederick Pollock, a member of the English historical school of law along with Maitland and Vinogradoff, was another strong Germanist. ${ }^{102}$ In a work published in 1883 on the land laws he assumed a position much like that of Kemble and Stubbs. 103 He believed in the early co-ownership of the land, indicating the existence of a free peasant community similar to that described by Tacituc. 104 Like Vinogradoff he found survivals of this system in the intermixed fields, village greens, and other rights

$100 \mathrm{Be} 11$, p. 31.

${ }^{101}$ Vinogradoff, The Growth of the Manor (London: George Allen \& Unwin, 1951), p. 157; J. Tait, "Large and Sma11 Hides," English Historical Review, XVII (April, 1902), pp. 280-82.

102 Five years older than Maftland, Pollock's name preceeded Maitland's as co-author of The History of English Law. His actual contribution to that work was quite small, no more than one-tenth of the total volume, and with the quality of that part Maitland was dissatisfied. Naitland, Letters, no. 109. In spite of the fact that his enthusiasm for the work soon flagged, Pollock refused to accept Maitland's offer to release Pollock from the commitment. He did not at any time suggest that Maitland be credited with the major contribution, and Maitland never insisted upon it in spite of his friends' urging. Fifoot, pp. $137 \mathrm{ff}$.

103F. M. Pollock, The Land Laws (London: Macmillan \& Co., 1883). 104 Ibid., pp. $187 \mathrm{ff}$. 
in common--pasture, waste, and wood.

Pollock disagreed with the legal theory enunciated by Blackstone and other legal writers holding that these lands belonged to the lord, who granted their tenants the priviledge of using them.

A great many of the manors now or formerly existing represent ancient communities in which, little by little, the authority of the community was engrossed by the most considerable man in it, until he became the lord and the other landholders became his dependents. 105

This change was accomplished by means of "a long series of encroachments and fictions" used by lords and lawyers acting in the interest of the lords, in order to make the people believe "the lord's will was the origin of those ancient customary rights which before were absolute." 106 Pollock's teaching and his writings which appeared throughout his long life (he lived to be ninety-one years of age) undoubted1y were influential in the continued acceptance of the thesis of the early free village community.

\section{WILLIAM ASHLEY}

Although the majority of historians of this period agreed with the tenets of the Germanist school Seebohm had a few supporters. Two of these, Denman Ross and John Earle, have already been mentioned, 107 but perhaps the staunchest and most outspoken was William James Ashley, an economist and an economic historian. Strongly influenced

$$
\begin{aligned}
& 105 \text { Ibid., p. } 41 . \\
& 106 \text { Ibid., p. } 47 . \\
& 107 \text { Supra, pp. 48-49. }
\end{aligned}
$$


by the German econonic thought of his day, he was the man chiefly responsible for introducing that thought to the English speaking world. His studies, however, convinced him of the Roman origin of the English manor.

of the group of historians we have considered, $\Lambda$ shley's background was that least likely to produce a university tutor. He was born in London in 1860 , of middle class parentage--his father was a journeyman hatter "who plied his trade with difficulty in an age of mechanized industry."108 The atmosphere of hard work, economic insecurity, and puritanism of his youth impressed upon Ashley the reality of economic problems and imbued him with strong religious convictions. lle distrusted the theories of economists whose lives rarely touched the working classes about whom they wrote. His evangelical upbringing gave him a sense of duty toward the men who toiled and sweated for their bread, and aroused in him a determination to employ his scholarship on their behalf.

Ashley received his early education at two small private schools in Southwark. On his second attempt he was awarded a scholarship to Balliol, Oxford, where he took a first prize in history. Unable to obtain a suitable position he lived at Oxford from 1881 to 1885 , eking out a living as a coach and tutor.

Without mney, without family influence, without social experience and poise, he made four unsuccessful attempts to secure a fellowship at one of the colleges. Not until 1885, when he

108 Janet Macĩonald, "Sir William Ashley (1860-1927)," B. E. Schmitt (ed.), Some Historians of Modern Europe (Port Washington, N. Y.: Kennikat: Press, 1942), p. 21. 
was elected a fellow of Lincoln College, was he able to enter his chosen profession. 109

His interest in history was stimulated at Oxford by the works of Stubbs, and the lectures of Arnold Toynbee, who introduced him to the classical economists. Between the years $1880-1884$ he made visits to Heidelberg, where he fell under the influence of German economists Kar1 Gustav Knies and Gustav Schmoller.

In 1888 he left England to accept a position as professor of political economy at Toronto. While there he wrote his best known work, An Introduction to English Economic History and Theory (1883-93). His later teaching positions were at Harvard, as the first holder of the Chair of Economic History in any country, from 1892 to 1901, and at the University of Birmingham where he went in 1901. While Ashley was pleased to obtain an academic post in England, it was not the kind of position in which he could continue the work he had been doing. His tasks at Birmingham were more practical than scholarly: he was responsible for transforming "abstract economics into something realistic and adapted to commercial needs" and for the organization of the first school of commerce in Britain. 110

With the publication of The Tariff Problem in 1903, a presentation of the case for a protective tariff policy, Ashley achieved a reputation as an expert in this field. He was convinced that adoption of the tariff was necessary for the welfare of the working man. He

${ }^{109}$ Ibid., p. 23.

$110 \mathrm{~W}$. R. Scott, "Memoir: 'Sir William Ashley," Economic History Review, Series I, Vol. I (1927), pp. 320. 
condemned the classical economists for their support of laissez faire and the fiction of 'freedom of contract.' Since they lacked experiential knowledge of the conditions existing in industry and commerce, such theoreticians had no way of judging whether or not their doctrines were actually beneficial to the people. As a result of his work in this area, and for his work during the war, Ashley was asked to serve on a number of important governmental committees and commissions on taxation, Industry, and trade, and as a reward for his services to the government he was knighted in '1917.111

These activities took up so much of Ashley's time that during the latter part of his life they overshadowed his career as a scholar. He has been characterized as a man with a brilliant mind, capable and interested in scholarly work, but tempermentally unsuited to "the contemplative life--a man of action and drive who needed more room for his energies than the library and the classroom provided."112

Some of $\Lambda$ shley's historical work represents the results of original research, but more is based on recognized secondary authorities or is a snythesis of the writings of other scholars, and the first decade of his maturity gave promise of a greater scholarly future than he ever achieved. 113

Ashley himself offered a more simple explanation for his choice of a carcer--financial need. A chair which might have paid a salary commensurate with his needs was not available in his speciality in England, and he did not want to spend his life abroad.

$111_{\text {Ibid. }}$

112 Ibid., p. 321.

$113_{\text {MacDonald, p. } 20 .}$ 
Ashley's woris fall into two principal groups: those on historical problems of an economic nature, and those concerned with contemporary economic situations. In the latter group are such works as The Railroad Strike of 1894 (1895); The Tariff Problem (1903); and The War and Its Economic Aspects (1914). In addition to English Economic History, the former group includes The Economic Organization of England (1914); Bread of Our Forefathers (1927); and "The English Manor," an introductory chapter to Fuste1's The Origin of Property in Land (1891). A collection of forty-five of his essays were published in one volume entitled Surveys, Historic and Economic (1900). Several of these are concerned with medieval agrarian problems, and a number of others are devoted to evaluation and criticism of other works in this field, including those of Seebohm, Vinogradoff, and Maitland.

In spite of the relative paucity of his writings, Ashley achieved a recognized place among economic historians, based primarily upon his English Economic History. This work was a pioneering effort in English speaking countries and tied him closely to the historical school of economics in Germany. ${ }^{114}$ The doctrines of this school were first enunciated in the mid-19th century by Wilhelm Roscher, Bruno Hildebrand, and Karl Knies, and were fully developed after 1870

114 It has been said of Ashley, however, that he was never an adherent of any school of history or economics: "such an allegiance would have been impossible for a man with his distrust of theories." MacDona1d, P. 25. 
by a group of which Gustav Schmoller was the leader. 115 The movement represented a "violent reaction" against the classic economics of Adam Smith and David Ricardo; it reflected very strongly the influence of llegelian philosophy; and its tenets were closely related to those of the historical school of law which had flowered somewhat earlier under the leadership of Savigny. Al.1 members of the historical school were united in their insistence upon the need for governmental intervention in the economic system, hence were opposed to the policy of laissez faire.

Ashley's position was not as extreme as that of the Germans, and though he admired Schmoller and held him in highest regard as his former teacher, he disagreed with many of his beliefs. Ashley's own work "reflects eclecticism and balanced scholarship."116 He sought to bring economics into the mainstream of history, and history to bear on the study of economics, in the conviction that each discipline would benefit thereby. He held that two causes had "gradually modified the character of economic science." These two causes were "the growing importance of historical studies and the application

115For a summary of the "historical school of economics," see: J. F. Bel1, A History of Economic Thought (New York: Ronald Press Co., 1953), pp. 329-58; L. H. Haney, History of Economic Thought (New York: Macmillan Co., 1967), pp. 537-51; E. Heimann, History of Economic Doctrines (London: Oxford University Press, 1945), pp. 177183.

$$
116 \mathrm{~J} \text {. F. Bel1, P. } 355 \text {. }
$$


to society of the idea of evolution."117

In the development of Asliley's description of the progress of English economic history the question "whether that history began with a population of independent freemen or with a population of dependent serfs" becomes important. ${ }^{118}$ Because there are no records of the beginnings of English history the question may never be conclusively answered, but in his opinion some speculations are more soundly based than others. A view of the problem based on an understanding of the 1lth century manor in all of its aspects is more important than one based on an analysis of small details and isolated situations. Thus he is critical of the methods used by Vinogradoff and Maitland, and.to some extent that used by Seebohm, though he agrees with Seebohm's conclusion.

In English Economic History Ashley describes the manor as the earliest economic institution for which concrete evidence exists. His. description is based on custumals and rentals; the legal materials, he holds, only serve to distort the picture "because [legal] definitions throw a fallacious veil of uniformity over widely differing circumstances. "119 He finds that in the 11 th century the whole of the central part of England was covered with manors of substantially the same character. This, he believes, is proof that there were no

117W. J. Ashley, An Introduction to English Economic History and Theory (2 vols.; 2nd ed.; London: Longmans \& Co., 1892), Vol. I. pp. ix, $x$.

118 Ashley, "The English Nanor," p. vii.

119 Ashley, English Economic History, p. 20. 
original free communities. Had there been, some of these should have survived, or at least a number of intermediate stages should be discernible--cases in which the lord used his servants to cultivate the demense and only presided over a court for the other tenants; cases where "he received suit and rent without labor"; and others where only occasional labor services were rendered. "We should not expect, on the theory of the gradual fall of free communities, that the services of the tenants would be so burdensome, and so uniformly the same." 120 Thus the freemen of the late middle ages were not survivals of a free village community but emancipated villeins. 121

Seebohm's explanation of the existence of the three-field system in England as being either pre-Roman or a Roman survival does not satisfy Ashley completely, and he feels there are many aspects of the problem which need to be explored.122 He finds, however, that the strip system is easily accounted for on the basis of Welsh laws, "applicable to an earlier social stage than any of which we have documentary evidence among the English," which regulate common ploughing.

These lay down that every year the first strip that is ploughed shall be allotted to the ploughman, the next to the irons (i.e. to hiln who had fumished the ploughshare, etc.), the next to the first oxen, the driver and the plough (i.e. the carpenter

120 Ibid., p. 15 .

121see: W. Ashley, "The Character of Villein Tenure," Annals of the American Academy of Political and Social Science, I. $(\overline{890-91})$, pp. 412-25.

122 Supra. Pp. $45-47$. 
who made and repaired $i t)$. Thus he who furnished one ox would have one strip out of every ten or so; those furnishing two, twice as many. 123

In his essay on "The English Manor," Ashley discusses the validity of the Mark theory. Here his method is primarily one of internal logic: he marshals the arguments in favor of the theory and attempts to show that they are logically inconsistent, though he concludes that even Fustel failed to consider all of the pertinent factors. Relying chiefly on Fustel's rork, Ashley's first contention is that definite proof of the existence of the Mark on the continent has never been made. Second, even if the Mark existed in Germany there is no evidence that it ever became established in England. Finally, he holds that the method of 'comparative custom,' suggested by Maine, fails to verify the presence of an institution similar to the Mark either in Germany, India, or Russia.

In favor of the continuity of Roman influence in Britain he contends, first, conditions on the continent were a direct continuity of condtions that had prevailed under Roman rule. Second, since "the English manorial system was substantially, and in most of its detalls, similar to that which prevailed during the Middle Ages in Northern France and Westem Germany" it may be naturally concluded that "what was true of the Continent is true also of England." 124 Finally, field patterns provide firm evidence of the influence of Rome, for since the English did not have the three field system in ${ }^{123}$ Ashley, English Economic History, p. 16.
${ }^{124}$ Ashley, "The English Manor," p. xxviii. 
their homeland, they cannot have brought it with them to Britain. ${ }^{125}$

In summing up the problem Ashley states:

In the mediaeval manor there were two elements, the 'seigneurial' the relations of the tenants to the lord; and the 'communal' the relations of the tenants to one another. The mark theory taught that the seigneurial was grafted on to the communal. The value of the work of ii. Fustel de Coulanges and of $\mathrm{Mr}$. Seebohm is in showing that we cannot find a time when the seigneurial element was absent; and also in pointing to reasons, in my opinion conclusive, for connecting that element with the Roman villa. 126

It is Ashley's view that while the denise of the Mark has been sufficiently proved, and the continuity of Roman influence adequately demonstrated, there remains yet to be solved the mystery of the communal element. This question must be approached from "both sides of the subject--the economic as well as the constitutional and 1egal:127 Thie economic point of vicw has too long been neglected.

Ashley has been criticized chiefly for relying too heavily upon the writings of Fustel and Seebohm in his analysis of the manor as an economic unit. His work in the fleld remains important, however, for he was the first to offer the point of view of a man trained.both in economics and history. Recent economic historians tend to agree with his conclusions. 128

The historians discussed here by no means exhaust the list of those who have taken sides on the issue of the origin of property and

$$
\begin{aligned}
& { }^{125} \text { Ibid., p. } x \times x . \\
& { }^{126} \text { Ibid., pp. } x 1 i-x 1 i i . \\
& 127 \text { Ibid., xliii. } \\
& 128 \text { Finberg, p. } 401 .
\end{aligned}
$$


the status of the common man in early medieval times. It is doubtful that the issue can ever be fully resolved: what is remarkable is the earnest concern of historians with it--even today. In a widely used text, Anglo-Saxon England (1943), the second volume of the Oxford series on English history, Frank M. Stenton finds in a passage from Ine's laws proof not only of the existence of the open fields in the 7th century, but also proof that "the tenant is clearly a free man." 129 On the other hand H. P. R. Finberg, in The Agrarian History of England and Wales (1972), holds the evidence of the open fields denies such a theory and calls upon historians to cease "reading history backwards," and to proceed instead from the contemporary evidence offered by the land. 130

How can we account for such differences of opinion? To determine why a man thinks as he does is indeed a difficult task. The clues lie in his background, in the general milieu in which he lives, and in the way he reasons. In the case of our four 19th century historians the search will begin by examining the varying ideas and ideologies of the Victorian Era of which they were all a part, and proceed from there to more specific points of differentiation.

${ }^{129}$ Stent on, pp. 309-10; supra, p. 6 . 130 Finberg, p. 401; supra, pp. 5-6. 
CHAPTER IV

THE VICTORIAN ERA: IDEOLOGY AND INFLUENCE

Frederic Seebohm was born in 1833 and William Ashley died in 1927. Thus a span of almost a century was covered by the lives of Seebohm, Vinogradoff, Maitland, and Ashley. It was one of the most momentous centuries in all of England's history: it witnessed an unprecedented rise in prosperity and world power and saw the beginning of decline in greatness; it produced social and governmental reforms, known as the Victorian compromise, which was England's answer to violent revolution; itsaw scientific and intellectual development leading to drastic changes in man's view of himself and his God. For most of the century England had a soverelgn, Queen Victoria (18371901), whose name has become a household word characterizing the era.

This was the common environment which each historian we have discussed shared to some extent with his fellows. There were, however, wide differences in the more intimate details of their social backgrounds, differences of famlly,education, religion, politics, and in the case of Vinogradoff, of national origin. How, if at all, did these differences affect their opinions and judgments? Closely related to this question is that of methodology. Did the particular historical method used affect the conclusions they reached? 


\section{POLITICS AND IDEAS}

All of the 1mportant works of the historians who are the subject of this study were produced in the latter part of the 19 th century, after 1870--the 'late Victorian era.' In looking for influence upon their thought and its development, however, we must also take into account the earlier years, which were for most of them the t1me of their maturation.

Thus we shall consider the period in two divisions. The first, wh1ch encompasses the years 1832-1870, from the Great Reform B111 to the Franco-Prussian War, has been called 'an age of transition. 1 The Intellectuals of the period saw themselves living in a time when Eng1ish institutions and doctrines were undergoing a change, not from the Romantic period, or even the 18 th century, but from the Middle Ages to the Modern Era. ${ }^{2}$ The second division extends from 1870 to the middle 1920s. For reasons we shall mention later the Francom Prussian war ushered in a new epoch in English history, one which saw the Constitution fully developed in its modem form and English society finally democraticized. 3

\section{$1830-1870$}

From 1830 until 1837 William IV was King of England. After him

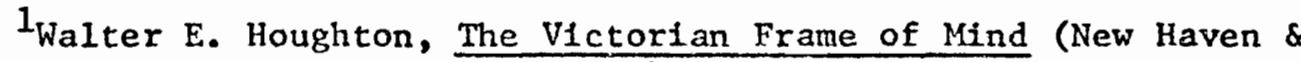
London: Yale University Press, 1971), p. 1.

2 Ibid., pp. 1-4.

${ }^{3}$ R. C. K. Ensor, England 1870-1914, Vol. XIV of The Oxford History of England, p. 1 . 
an eighteen year old girl, his niece Victoria, ascended to the throne and relgned for the remainder of the century. The power of government was not, however, in their hands: it had resided for a century and $a$ half in Parliament and 1ts leaders. The period from 1830 to 1870 was marked by two important factors: first, freedom from serious military conflicts on the continent and from rebellion at home; and second, the lack of political parties with strong lines of distinction or definite policies and principles. Parliamentary leaders, Sir Robert Peel, Lord John Russe11, Lord Palmerston, Lord Derby, Lord Shaftsbury, and others, resorted to coalitions and party switching in order to implement policies they supported. Only after 1868 with the emergence of Gladstone and Disraeli did party lines again become firmly established.

Industry and trade continued to expand at a fast tempo, propelled by the introduction of new machines and improved ways of transportation: macadam roads, railways, canals, and steamships. The repeal of the Corn Laws in 1846, under the sponsorship of Sir Robert Peel, established the policy of laissez faire advocated by Adam Smith in Enquiry into the Wealth of Nations (1776). Under this principle the manufacturer bought his materials as cheaply as possible and sold his product for the highest price he could secure. He excused himself for paying his workers only a minimum wage on the ground that it was his function to produce goods at the lowest possible cost in order to make them avallable to the greatest number of people. The problems created by increased industrialization caused considerable agitation for governmental and social reforms. 
Much of the reform legislation of the period has been credited to the influence of Jeremy Bentham (1748-1832), whose utilitarian principle of the 'greatest good for the greatest number' appealed to pragmatic Englishmen and became the tenet of the Liberal Party. Among important legislative acts credited to his influence are the Great Reform Act of 1832; Acts extending freedom of trade; those granting greater religlous and personal liberties; the Poor Act of 1834; and the Education Act of $1870 .^{4}$

Probably the most far-reaching in its effect was the Great Reform Act of 1832, which broadened the franchise considerably by giving the vote to the middle classes, chiefly to manufacturers, bankers, and other business classes. The bill was first opposed, but finally supported by the Lords, when it became clear it would be passed regardless of their opposition. The result of this legislation was a shift in parliamentary power from the aristocracy to the middle class.

It was not a democratic measure, and its authors did not appeal to democratic sentiments. Its purpose was to enfranchise property and intelligence, to enfranchise not the greatest number but those whose political power was most likely to promote the greatest happiness of the greatest number. 5

In 1867 a second Reform Bill was enacted which enfranchised the urban factory worker. This important measure doubled the electorate and established acceptance of the principle of democracy, though the

${ }^{4}$ D. C. Somerve11, English Thought in the Nineteenth Century (London: Methuen \& Co., 1957), pp.79ff. Bentham and his followers were known as the Utilitarians or Philosophic Radicals.

$$
{ }^{5} \text { Ib1d., p. } 80 .
$$


agricultural laborer was still without electoral power.

Although Bentham's philosophy was an influence on the reform legislation of the period it was not the most important factor involved. Primarily the causes of reform were economic. The wealth and prestige of the middle classes gave them the power necessary to force recognition of their interests. For the most part their strong advocacy of reform coincided with those interests: franchise reform, which gave them control of Parliament; repeal of the Corn Laws, which gave them control of world markets; and religious reform which, since most of them were Nonconformists, gave them greater religtous freedom and equality.

At the other end of the scale the economic condition of the poor stimulated reform movements: their poverty and their dissatisfaction had to be assuaged in order to avoid serious rebellion and the threat of revolution. Although movements such as Chartism, which demanded the franchise for the working man, were not successful in gaining their specific goals, they brought to public attention both the plight of the poor and their capacity for disrupting orderly govemment and society. Doctrines as diverse as those of Robert Owen and Feargus $0^{\prime}$ Connor posed the threat of socialism and anarchy; the middle and upper classes recognized the necessity of compromise. The Reform Bill of 1867, the Factory Reform Acts, the Education Act of 1870 were all passed partially under pressure from the lower economic strata.

$$
\text { I Ibid., p. } 80 \text {. }
$$


A third factor which had a strong influence upon the reform movement was the work of the Evangelical philanthropists. These men came from all classes and had in common religious ardour and great secular passion for social reform.

...during the nineteenth century Evangelical religion was the moral cement of English society. It was the influence of the Evangelicals which invested the British aristocracy with an almost Stoic dignity, restrained the plutocrats newly risen from the masses from vulgar ostentation and debauchery, and placed over the proletariat a select body of workmen enamoured of virtue and capable of self-restraint. 6

William Wilberforce, prominent in the antimslavery movement, and Lord Shaftsbury, the man primarily responsible for the factory acts, are outstanding examples of evangelical reformers.

The number of Nonconformists in England increased enormously during this time, particularly Methodists, who were strongly evange1ical in their beliefs and narrowly puritanical in their soctal attitudes. Within the Church of England a group known as the Evangelicals. shared many of the religious and social codes of the Nonconformists, as well as their disposition for reform. A counter-movement within the Anglican Church was the Oxford Movement, led by John Henry Newman among others. These men feared the nonconformist attitudes developing within the church would destroy it; they sought a return to strict ritual, stressed the doctrine of the apostolic succession, and advocated greater spiritual dedication of the clergy. Their thinking was close to Roman Catholicism, and some of them, including Newman,

${ }^{6}$ E. Halévy, A History of The English People in the Nineteenth Century trans. E. I. Watkin and D. A. Barker (6 vols. ! 2nd ed.; London: Ernest Benn, 1950), Vol. III, pp. 163-64. 
eventually became Catholics.

In spite of the religious fervor of the period it was one of intellectual and religious doubt. John Stuart Mill (1806-1873) expressed Victorian doubt in this way:

Scarcely any one, in the more educated classes, seems to have any opinions, or to place any real faith in those which he professes to have... Those who should be the guides of the rest, see too many sides to every question. They hear so much said, or find that so much can be said, about everything, that they feel no assurance of the truth of anything. ${ }^{7}$

Before 1.859 the Victorians were unsure not so much of the existence of 'truth' as of the best way to discover it. After the publication of Charles Darwin's The Origin of the Species in 1859 the problem became more complex. How could the authority of scripture be reconciled with the new scientific theory of man's creation? Men began to question the existence of God and the idea of progress toward an established goal; they began to wonder if 'truth' in any fleld could ever be more than a relative concept.

By the end of this 'age of transition' two clearly defined characteristics have appeared: the existence of a bourgeols industrial society, and an increasing doubt about the nature of man, society, and the universe. 8

\section{$\underline{1870-1920}$}

When the guns of the Franco-Prussian war first thundered in earnest on 4 August 1870 a new epoch began, although Europe at the time did not know it. At midnight of the same day just

7J. S. Mill, Letters, no. 2, quoted in Goughton, p. 13. 8 Houghton, p. 22. 
forty-four years later the sands of Great Britain's ultimatum to Germany ran out; and with them the epoch ended.9

On the international scene the Franco-Prussian war transferred from France to Germany ascendancy over Europe and triggered events leading eventually to the First World War. For England the period was important internally: (1) it witnessed the conversion of the English government into a democracy; (2) itsaw the spread of the educational system into one which Included all the people; (3) it marked the demise of the English agricultural system; (4) during this perlod the English manufacturing industry was first challenged by outside competition; and finally, (5) the concept of Empire underwent drastic changes, and the foundations of the British Commonwealth of Nations were laid. 10

Queen Victoria ruled until 1901; she was succeeded by her playboy son, Edward VII, who proved to be an able and popular monarch. In 1910 George V took his father's place; he was grave, conventional, conscientious, somewhat unsocial and anti-intellectual--a good deal more like his grandmother than his father. 11 Disraeli and Gladstone were the great statesmen of the period, and their personal duel attracted the kind of attention top sporting events do today. Disraeli revived the shattered Tory Party and was close to the Queen; Gladstone founded the Liberal Party and was a staunch supporter of Irish Home Rule--the

$$
\begin{aligned}
& { }^{9} \text { Ensor, p. xix. } \\
& { }^{10} \text { Ibid., pp. xix-xxii. } \\
& { }^{11} \text { D. H. Willson, A History of England (New York: Holt, Rinehart }
\end{aligned}
$$
and Winston, 1967), p. 742 . 
1ssue which led finaliy to the Party's destruction. They were almost evenly matched:

[In his prime Gladstone] displayed all-round parliamentary powers, which it is difficult to believe can ever have been quite equalled, and which in one situation after another simply astounded friend and foe alike. It is not the least part of Disraeli's credit that in presence of such a human tornado he never lost his footing or his nerve, but....was always able to maintain a fighting front. 12

There were other leaders of note during the perfod: Lord Salisbury, Arthur J. Balfour, David Lloyd George, Stanley Baldwin, James Ramsey MacDonald. The orderly process of government continued and, under the pollcy of 'gradualism' already begun, changes were made without disrupting the continuity of political institutions. By the early 20th century, with the reform of the House of Lords and the rise of the Labor Party, Victorian liberalism had given way to 11beral socialism.

The utllitarian principle of Bentham which, in the earlier perlod had been interpreted to support individualism and laissez faire, was now used as a philosophical basis for state intervention. Individual efforts had failed to relieve the vast economic and social differences in Industrial England, and an increasing number of people advocated collectivistic and socialistic practices as the only way to bring about equality and reform. The term 'collectivism' has been generally subsumed under 'socialism'; the latter, however, may be defined as a complete system of political and economic thought, and

$$
{ }^{12} \text { Ensor, p. } 2 \text {. }
$$


the former as group efforts to obtain legislation within the older sys tem. 13

Collectivist legislation of this period included the Factory Act of 1878, the Workmen's Compensation Acts of 1880 and 1897, enacted under the sponsorship of Joseph Chamberlain, the old Age Pension Act of 1908, and Lloyd George's Insurance Act of 1911. These acts, all in the interest of the workingman, extended "the sphere of public control at the expense of the old freedom of individual enterprise."14 Collectivism had the long range effect of spreading what was really socialistic control over many areas without alarming the practical man who opposed socialism in theory, but saw the necessity for many of the measures listed above.

The early socialist movements which began with Thomas Spence and Robert Owen had died out. The depressed economic conditions in England during the decade 1875-1885 furnished fertile soll for the movement's revival. The new socialism was, however, of foreign origin; it received its philosophical basis from Henry George's Progress and Poverty, and from the writings of Karl Marx. In $1881 \mathrm{H}$. M. Hyndman, a disciple of Marx, founded the Social Democratic Federation which advocated a revolutionary type of soclalism. The English people were not attracted to this doctrine: they wanted reform but not revolution. In 1883 the Fabian Society was founded and had as one of its basic.

$$
{ }^{14} \text { IbId., p. } 200 .
$$


bellefs, 'the Inevitability of graduallsm.' "Soclalism would come by Installments, through the instrumentality of guileless Liberals and Conservatives." 15 Some of the well known leaders of the Society were Beatrice and Sydney Webb, Sydney Oliver, Annie Besant, and Bernard Shaw. Their program was outlined in Fablan Essays in SocialIsm (1889) and proposed as its primary reform the gradual nationalization of land.

The Dock Strike of 1889 marked the beginning of British socialIsm as it has later developed. Among the strike's effects were the democratization of trade unionism and the diversion of socialism from radical idealism to practical efforts to influence government and legislation. In 1899 the Trade UnIon Congress supported a plan to finance the Labor Party for parliamentary purposes. A Labor Representation Committee was established, which included representatives of the Trade Union Congress, the Independent Labor Party, the Fablan Society, and the Social Democratic Federation. In effect this action established the Labor Party, with Ramsay MacDonald as its first secretary. 16

The rise of socialism was accompanied by a renewed policy of 1mperialism. It had been the belief of many Englishmen, following the repeal of the Corn Laws, that the colonies had become an unnecessary burden and should be gotten rid of completely; Richard Cobden and

$$
\begin{aligned}
& { }^{15} \text { Ibid., p. } 209 . \\
& { }^{16} \text { Ibid., pp. } 211-12 .
\end{aligned}
$$


John Bright were articulate spokesmen for this attitude. When it became apparent, however, that free trade was not going to be adopted by all other nations, that militarism was not a thing of the past, and that to compete on the international scene England would have to draw her colonies closer rather than let them go, a new school of thought arose advocating imperialism. This policy was clearly enunciated by Disrae11 in 1872; Rudyard Kipling made of it a moral duty-the 'white man's burden'; its result was British expansion into the Far East and Africa. The Boer War, however, showed that imperialism was not fully supported at home and that it could provoke hostile reactions abroad resulting in diplomatic isolation. In the meantime, as an outcome of the Durham report made to Parliament in 1839, three colonies, Canada, Australia, and New Zealand, became self-governing between the years 1867 and 1907. This proved to be the beginning of a pattern which eventually led to the formation of the Commonwealth of Nations and the abandonment of the concept of Empire. 17

Growth continued in the field of education. The Education Act of 1870 had made it possible for every English child to receive elementary schooling. Technical education and expanded university services were provided by 1900. Secondary schools supported by public funds were created from the existing smaller 'grammar schools' by an Act of 1902; these were administered by local authorities in the same manner as the elementary schools. By 1914 a group of new, firstrate universities were spread over England, and London had developed

${ }^{17}$ H. J. Schultz, History of England (2nd ed.; New York: Barnes \& Noble, 1971), pp. $268 \overline{\mathrm{f}}$. 
greatly as an educational center. Ruskin College, established at Oxford in 1899 to train leaders for the working-class movements, was moved to London in 1908, where it was to be fully supported by unions in order to provide "independent working-class education on Marxian IInes." 18

The latter part of the century saw an increase in religious toleration and a decrease in church membership, with a greater loss In the Church of England than among the nonconformist sects. Most of the people still adhered to the strict moral code of the earlier era In spite of the undermining of its religious base. The upper classes were both more religious in outward appearance and more moralistic in their conduct than the working classes; in this there was no great change from the earlier period. With Victoria's death evangelicalism declined: the life style of the new king set an example of laxity In religious observance and moral attitudes; many of the 'blue laws' were repealed; and new standards of conduct became acceptable.

The conflict between religion and science continued, but after 1870 science gained the upper hand and by the end of the century was clearly the victor. There was, however, little foy in the victory. The pessimism of the day was reflected in the writings of men like Arthur Balfour.

Man, so far as natural science by itself is able to teach, is no longer the final cause of the universe, the Heaven-descended heir of all the ages. His very existence is an accident, his story a brief and transitory episode in the life of one of the meanest of the planets... Nor will anything that is be better

18 Ensor, pp. 146-152, 316-22, 536-40. 
or be worse for all that the labour, genius, devotion and suffering of man have striven through countless ages to effect. 19

For all practical purposes the war which began in 1914 brought a hiatus in political and social movements. Activity of a political nature which was unnecessary to the war effort virtually ceased until after the Armistice of November 1918. Then the changes which had begun before the war continued at a more rapid tempo, and a whole set of new polfcies and theories emerged.

This brief summary of politics and ldeas in the 19 th century has revealed certain predominant themes: Industrialism, Benthamism, Evangelicalism, Darwinism, scepticism, democracy, socialism, and imperialism. Indfrectly these doctrines must have affected the lives of our historlans in many ways. Specific Influence, if it existed, however, can be detected only by a closer examination of their lives.

\section{SOCIETY AND EDUCATION}

\section{Frederic Seebohm}

Seebohm, as we have seen, ${ }^{20}$ was born into a middle class family of modest means and strong evangelical beliefs. His education was limited; primarily because of lack of money he did not attend a University; and though he read briefly for the bar he was apparently never admitted to practice. When he married wealthy Mary Ann Exton the pattern of his life was set--he settled in Hitchin where her

${ }^{19}$ A. Balfour, The Foundations of Belief, p. 29, quoted in Sommerve11, p. 223.

${ }^{20}$ Supra, $\mathrm{Pp} .39-41$. 
family lived and entered her father's business.

Three factors appear to have been of primary significance in Seebohm's life. Perhaps the most important of these was his religion, for he was a devout Quaker with deep religious convictions. In England in the 19 th century the Quakers were isolated to a considerable extent by their beliefs, a fact which led to intermarriage and to the development of a strong clan feeling. These people formed a tightly knit group; they were chiefly prosperous bankers and merchants, "with enclaves in all the principal cities and particular strongholds in Norfolk, Hertfordshire, Yorkshire and the West country."21

The Quakers adhered to their own strict doctrines and developed political and social traditions which were followed with some uniformity throughout the century.

English politics in the nineteenth century were... as much a matter of denomination as of class. Political and social divisions remained very largely religious. The leading Conservatives in each town were generally the keenest churchmen. Their most active Liberal opponents were usually dissenters or anti-clericals. The Seebohms certainly fitted into this pattern. 22

A Quaker tradition, which was shared to some extent by all evangelical $f$ aiths, was "the sense of duty and social responsibility which implies that one is on earth to improve the lot of others." 23 Thus we find Seebohm involved in the community activities and 'causes' of his day: a member of the Hitchin Radical Association, an active Liberal in local

$$
\begin{aligned}
& 21_{\text {Glendinning, p. } 10 .} \\
& 22 \text { Ibid., p. } 40 . \\
& 23 \text { Ibid., p. } 10 .
\end{aligned}
$$


politics, a thwarted Parliamentary candidate.

A second influential factor in Seebohm's life was the economic one. During his early life he lacked money; this lack prevented his obtaining the kind of education he might otherwise have had; but more important, it gave him an awareness of the problems of the lower classes and a sympathy for their difficulties. As a boy he had been impressed by the struggles of handloom weavers in West Riding against the encroachment of Industrial machinery upon their lives. From that time he maintained an interest in the eçonomic conditions of the common Englishman. When, with his marriage he acquired considerable wealth, it proved to be a mixed blessing. 24 It gave his father-inlaw the ability to direct his $11 \mathrm{fe}$, and thus to put an end to his polftical ambitlons; whle at the same time his wife's money made it possible for him to pursue his academic interests as a serious and time-consuming avocation. 25

Finally, Seebohm's lack of formal education was a determinative factor. Had he been able to attend a university he might well have stayed in the academic world; his personality and his brilliant mind suited him to that life. His lack of academic training was a handicap to his historical studies, and the fact that he was able to produce

24 Apparently the Extons had 1ittle confidence in Seebohm's business acumen. He remained a junior associate at his father-inlaw's bank all his 1 ife and when his widowed mother-in-law died she left all of her considerable properties to her daughter, "for her own separate use, free from the control of the said Frederic Seebohm." Glendinning, pp. 2-3.

${ }^{25}$ Seebohm spent fifteen years of intense research before completing The English Village Cormunity. Thompson, p. 386. 
works which attained recognition anong scholars is a credit to his high intelligence and his remarkable persistence. Vinogradoff, in his obituary notice honoring Seebohm, pointed out that he had the merits and defects of the self-taught man. On the one hand he used an Inventive, unorthodox approach, and on the other he failed to give attention to contemporary work in the field. He was like "a brilliant chess-player, always intent upon the attack, but sometimes failing to guard his position against the adversary."26

\section{Paul Vinogradoff}

Vinogradoff spent his youth and much of his adult iffe in Russia. These were undoubtedly the years most influential in the development of his character and his thought. At mid-century Russia was primarily an agricultural country. Thres-quartere of ite total population of about sixty million were peasants of three types: state serfs living on state lands; landowners' serfs living on lands belonging to the hereditary nobility; and a comparatively small number of free peasants owning their own few acres or tiny plot. The landholding class consisted of around 250,000 nobles, many of whom owned only a few serfs, while a small number had great estates with hundreds of serfs.

The government rested on a three-fold base of Crown, nobles, and serfs, and was administered by an incompetent, corrupt, Crownappointed bureaucracy. Its most oppressive branch was the police,

${ }^{26}$ Vinogradoff, "Ob1tuary: Frederic Seebohm," Collected Papers, Vo1. I, pp. 262-76. 
whose duty $1 t$ was not only to enforce the law but to scrutinize minutely all political activity. An educated professional class formed the nucleus of the intelligentsia. These people were aware of the difference in Russia's development and that of Western Europe; the majority were opposed to the regime, though they were not necessarily sympathetic to revolutionary ideas.

The intelligentsia were divided into two main groups: the Westernizers and the Slavophils. The latter believed Russia's problems could be solved only through the development of her own unique culture; by adhering to the old orthodox falth; and by tightening the sense of commity between the people themselves and between the people and the Tsar. They rejected the rationalism and individualism of Europe which in thelr eyes had proved to be dissolving and disintegrating forces; technological and cultural advances in the West had only brought additional burdens. The Slavophils advocated governmental reform by means of a revival of the Zemsk11 Sobor, the consultative assemblies of the people which had been used in the 16 th and 17 th centuries.

The Westernizers, on the other hand, held that Russia so far had done little to advance human thought and culture; and that before any real step forward could be taken westernization of the society and the economy was necessary. Some of this group believed reforms could be carried out within the framework of the present governmental structure, leading eventually to a constitutional monarchy. Others advocated a complete overthrow of the autocratic regime as the only 
means of alleviating the miseries of the people. 27

The last half of the 19 th century were years of both reform and autocracy. The great reforms of the $1860 \mathrm{~s}$ and 1870 s, instituted during the reign of Alexander II, were far reaching, but they failed to revolutionize Russian society. The serfs were emancipated in February, 1861, but continued state control and supervision, financial burdens, and communal regulation of peasant affairs made the life of the peasant appear very much as it was before the emancipation. The Zemstro Statute of January, 1864, was an important step toward the establishment of democratic local self-government, but the gentry still remained in control and were themselves never entirely free of pressure from the central government. The judicial reforms of 1864 constituted important gains for the people, but when lawyers attempted to use the new codes in defense of individuals against the government, conservative officials demanded revisions. Reorganization of the military system and relaxation of the censorship rules were reforms of some lasting significance.

Reforms in the educational system were desperately needed. Following emancipation the zemstros and municipal dumas were allowed to establish elementary schools which admitted peasant children. Conservative bureaucrats, however, feared the influence of education among the lower classes and took measures to control the schools. As

27 On social classes in Russia during this perfod see: H. SetonWatson, The Decline of Imperial Russia, 1855-1914 (New York: Frederick A. Praeger, 1965), pp. 5-24. 
early as 1864 secondary education became democratic in theory, although tuition fees served as a continuing discriminatory device. At the university level, also, there was reform: faculties, 1ibraries, and facilfties were improved and new schools were opened. The universities were, however, subject to governmental supervision; qualified and gifted scholars whose views did not agree with those of the government falled to gain university posts or were dismissed from those they held. After the assassination of Alexander II in 1881, educational policies became even more conservative, as the feeling grew among bureaucrats that the rise of liberal and revolutionary ideas was due to the teachings of the zemstro schools and to the doctrines of radical scholars. At all levels of education there was a return to the principleg of N1cholas I's reign: church schools replaced zemstro schools at the elementary level; attempts were made to restrict the gymasiums and universities to the gentry; more rigid criterla were imposed in the selection of faculty. The result was a decline in both the quality and quantity of education at a time when Russia greatly needed a literate population, as well as scholars and scientists, to bring about internal stability and to maintain a place in world affairs. During this period the revolutionary movements, which had begun earlier in the century with groups like the Decembrists in the $1820 \mathrm{~s}$ and those centering around Herzen and Belinsky in the 1830 s, continued to develop. The Populist movement, said to have its roots in Herzen's doctrines, gained momentum with the work of Bakunin and especially Chernyshevsky. This group endorsed a soclalism, based on the tenets of Proudhon, Saint-Simon, Fourier, and other French socialists, which 
upheld democratic ideals and emphastzed the struggle between social and economic classes as the determining factor in politics. They rejected rigid Marxist determinism, however, and insisted that the individual and human freedom were basic elements in society and history. In the latter part of the century, leaders in the movement such as Mikhallovsky contended that increasing capitalism could be blamed for the poverty of the lower classes. They proposed to improve agricultural conditions and to transform industry from its capitalist form to a socialist structure by means of the peasant commune.

Opposing the Populists were the 'legal Marxists' who held that it was necessary for Russia to go through a period of capitalism, as had other European nations, before the soctalist state could be achieved. Eventually this group split into two camps the 'economists', whose doctrines were set forth by Struve and Tugan-Baranovski, advocated cooperation between the existing government and the lower classes in order to achieve the desired changes; the Marxists, supported by men like Plakanov and Lenin, believed a rigid separation of the classes should be maintained in the struggle of the workers and peasants to bring about change in the structure of the society. Because censorship prevented any statement of political aims the debate among these groups was maintained on a philosophical level; they were all in effect revolutionary movements, whose goal was destruction of the autocratic state. 28

${ }^{28}$ On Russia during this period, for a general history see: E. C. Thaden, Russia since 1801 (New York: John Wilcy and Sons, 1971); on the rise of the revolutionary movements see: $F$. Venturi, Roots of Revolution (New York: Alfred A. Knopf, 1960). 
It was into this Russia of change and turmoil that Vinogradoff was born in 1854. Stability was provided, however, by his middle class family--conservative in politics and orthodox in religion. 29 His father, in his position as a director of schools at Moscow, apparently received an income large enough to provide for his big family and at the same time help his son secure the finest education Russia had to offer. Vinogradoff took full advantage of his opportunities, winning honors and an international reputation for high scholarship. He not only had a brilliant mind, he was a first class musician, a linguist without peer, and a superb athlete. The greatest influence upon his early life was his mother; it was she who pleaded for an academic rather than a military career for him; and from the year of his father's death in 1885 until his marriage in 1897, at the age of forty-three, they were very close.

Vinogradoff's studies had given him a deep interest in history, and a great reprect for 1 aw--both as a tool of order and justice and as historical source material; his work with Brunner and Schroder in Germany imbued him with a Germanist point of vieb on many basic questions. 30 Historical thought, he believed, was primarily 'snythetic' In character:

\section{${ }^{29}$ Supra, pp. $51-57$.}

${ }^{30}$ In 1902, Vinogradoff collaborated with Brunner and Schröder in an article attacking Wittich who had questioned the thesis of the freeman in early medieval Europe. Stephenson, p. 272, fn. 34 . Supra, pp. 15-16. 
...so far as it [history] deals with social realities it has to treat of complex states and complex processes, and its main object is to estimate and reflect the peculiar concentration of various elements in the shape of individuals, nations, events. In any case tt must pave the way for such estimates by a careful examination of evidence. And as for the final reconstruction, it will depend both on reflective comparison and deduction, and on artistic intuition. 31

For this reason he found Marx's interpretation of historical development unacceptable. According to Vinogradoff, Marx's theory was:

an attempt to unite economic analysis and the concrete process of history into one comprehensive scheme, which, once recognized, cannot remain a mere piece of learning, but ought to serve as a direction and an incitement to practical action. 32

The strength of this theory is that by considering "the 11 fe of humanity" from only one point of view "a strong light [is thrown] on the importance and influence of the economic factor in the process of evolution." Its weakness is that by treating all other factors, political, religious, artistic, scientific, philosophical, as mere adjuncts to the economf one, "Marxists expose themselves to the certainty of miscalculation and misinterpretation." 33

The synthetic view of history, in Vinogradoff's opinion, gave history a unfque value in combination with other studies. Particularly useful was the combination of law and history. He agreed with the tenets of the 'historlcal school of 1aw,' which held that law evolved from custom and tradition, and that even statutory law reflected this

\section{${ }^{31}$. Vinogradoff, Outlines of Historical Jurisprudence (2 vols.:} London: Oxford University Press, 1920), Vol. I, pp. 73-74.

$$
\begin{aligned}
& 32 \text { Ibld., p. } 80 . \\
& { }^{33} \text { Ib1d., pp. } 80-81 .
\end{aligned}
$$


evolutionary process. This school rejected the concept of law as a body of 'a priori' rules imposed from above by a sovereign or other ruling body, and represented a reaction against natural law doctrines. 34 Under the view of the historical school, law and history were mutually dependent and neither could be successfully interpreted without consideration of the other. 35

Thus Vinogradoff found that a 'dangerous miscalculation' of the Marxian doctrine, both from a scientific and from a practical point of view, was "the destruction of the domain of law" under the pretext that it is merely "a reflex manifestation of the preponderance of one or the other economic class." 36 For example, the institution of slavery was not simply the result of economic factors, but of "a combination of economic explottation with moral and political views which had a development of their own and crystallized in a definite body of law." 37 The abolition of slavery could be attributed to a similar combination of factors, leading to a change in the legal rules of conduct. In a like manner the upper classes, motivated by religious and moral purposes, have sometimes acted against their own economic interests in initiating and supporting reform legislation for the benefit of other groups.

\section{pp. $128 \mathrm{f} \overline{\mathrm{f}}$. \\ ${ }^{34}$ Supra, pp. 11, 29; Vinogradoff, Historical Jurisprudence,}

35"Law is frozen history. In an elementary sense everything we study when we study law is the report of an event in history, and all history consists of such reports and records." C. J. Friedrich, The Philosophy of Law in Historical Perspective (Chicago; University of Chicago Press, 1963 p. 233.

36 Vinogradoff, Historical Jurisprudence, p. 81

37 Ib1d. 
In his concept of the state Vinogradoff rejected the theories of both Rousseau and Locke.

As for the doctrine of a 'general w111,' It has been the stumbling-block of political theories which have attempted to work out the notion of the state as a subject of right too closely on the pattern of moral personality. The same may be said of the notion of 'natural rights' as the basis of political combination. 38

He was more inclined to agree with Bentham's statement that "right is the creature of law." The works of Sidney and Beatrice Webb 1llustrate, he held, the necessity of close interdependence between the polftical and social organization of a nation. Without necessarily endorsing their advocacy of the socialist state he approved the practical aspects of their doctrine as opposed to the "Utoplan dreams of Stateless mankind" advanced by the Marxists. 39

These views reveal clearly Vinogradoff's position as a 'liberal' by either 19 th century Russian standards or late Victortan England classifications. During his years as a student at the University of Moscow he had moved away from the orthodox conservatism of his famlly. However, he never became a radical or a revolutionary as did many of his fellow professors; instead he found the Ideal form of government in the English constitutional monarchy and he endorsed England's policy of gradual change and reform. He was aware of the basic difference In the attitude of the two countries toward reform--the unyielding position of the Russian aristocracy in relation to the peasants and workers, the willingness of the English upper and middle classes to

$$
\begin{aligned}
& 38 \text { Ibid., pp. } 90-91 \\
& { }^{39} \text { Ibid., p. } 96 .
\end{aligned}
$$


compromise. The educational system was, he belleved, one of the chief reasons for Russia's fallure to catch up with the western nations. In order to break with tradition and Institute a process of change along democratic lines it was necessary to create a broady educated middle class and a literate peasantry. Vinogradoff worked in many ways to bring about educational reforms, but without success. It was this failure which convinced him of his inability to help solve Russia's problems and led to his emigration to England.

There he fitted well into the group of gentry and scholars with whom he was already acquainted: his interests, his politics, his manner of life were much the same as theirs. Vinogradoff and Maitland were close friends; the questions with which Vinogradoff was concerned in Villainage and Maitland in Domesday Book and Beyond were simliar in many respects, and were the subject of conversation and correspondence between the two men. 40 vinogradoff, in discussing the English translation of Villainage had apparently suggested to Maitland that the interpretations of Maine, Stubbs, and Seebohm on the question of freedom of the early English peasant could be attributed to their political leanings: that Maine and Stubbs were liberals supporting freedom and Seebohm a conservative holding out for original serfdom. Maitland pointed out that this would be received in England as a paradox.

40 Fifoot, p. 145; Maitland, Letters, nos. 28, 43, 49-51,59,62, $97,104,109$ on Villainage; no. 164 on Domesday Book; no. 286 on
Folkland; nos. 424,428 on Growth of the Manor. 
A11 that you say about Stubbs and Seebohm and Maine is, I dare say, very true if you regard them as European, not merely English, phenomena and attribute to them a widespread significance-and doubtless it is very well that Englishmen should see this. Still, looking at England only and our insular ways of thinking, I see Stubbs and Maine as two pillars of conservatism, while as to Seebohm I think that his book is...utterly devold of political importance... 41

Vinogradoff was also well acquainted with Seebohm, and as Villainage and The English Village Community were in preparation at the same time they occasionally discussed the bastc question involved In the two books--the origin and nature of the manor.

It was natural enough that Frederic Seebohn should be one of his friends--he and Vinogradoff were working, almost 1iterally, in the same field. Vinogradoff cathe down to Hitchin several times to talk to Frederic. The two would pace up and down, up and down, their hands behind their backs, in their garden fust outside the drawing-room window--discussing the usual subject. 42

It is, of course, impossible to say to what extent Vinogradoff's conclusions were affected by the opinions of elther Maltland or Seebohm; but we do know that he was caught up in the debates of the day among English scholars on questions of medieval history, and to some extent was both stimulated and affected by the attitudes and opinions of these men.

Outlines of Historical Jurisprudence shows that Vinogradoff's scholarship was broad as well as deep; although his emphasis was upon law and history, within his grasp as well were philosophy, psychology, sociology, and theology. His approach to problems was objective; his

$$
\begin{aligned}
& 41_{\text {Fifoot, }} \text {. } 122 \text {. } \\
& 42 \text { Glendinning, pp. } 41-42 \text {. }
\end{aligned}
$$


conclusions rest on carefully evaluated evidence. In other words, his analyses bear all the marks of a great legal mind at work. Ashley has said of Villainage that it "illustrated throughout the difference between legal analysis and historical construction." At the same time he credits Vinogradoff with the ability to put himself wholly into the period he is describing--surely the mark of a great historian.

He has arrived at a knowledge of legal opinion and procedure in those centuries [13th and 14th] which would be more than worshipful in an Englishman and is nothing less than terrifying in a foreigner. Could he have been bortowed from a later age and transferred from the professor's desk at Moscow, in the nineteenth century, to the English judicial bench in the thirteenth, his colleagues would never have discovered that he had not always been one of themselves. 43

Perhaps it is possible that in Vinogradoff the dichotomy between the legal mind and the historical mind was overcome.

In attempting to sum up the influences which affected Vinogradoff's intellectual development several points becorne apparent. First, his early upbringing and education marked him with a sense of conservatism that remained a part of his ilfe; second, his broad education gave him a thorough grounding in law and history, a capactty for careful and minute research, and a logical approach to historical problems; third, the autocratic and unjust governments of Imperial Russia were unacceptable to him, but his faith in the common sense of the Russian people gave him the courage to work for educational freedom and opportunity which he felt sure would lead the way to a more democratic government; fourth, he saw in the Russian revolutionary movements not ${ }^{43}$ Ashley, Surveys, pp. $43-44$. 
liberalism or greater freedom for all men, but a threat to any just and reasonable government; finally, in England his association with upper-middle class intellectuais reinforced his distrust of revolution and his innate conservatism.

\section{Prederic Maitland}

Maitland, as we have seen, came of distinguished forebears-lawyers, scholars, and civil servants. 44 Both of his parents were dead by the time he was ten years of age and he was raised by a maiden aunt. His education followed the typical pattern of the upper middle class in Victorian England. He attended Eton, Cambridge, and then entered IIncoln's Inn--one of the four ancient Inns of Court where England's barristers are trained. Maitland's talents lay not with law, however, but.with history.

A lawyer is concerned with the past in the form of precedents, but the context of those precedents is of little importance to him. The 'legal' mind has been characterized in this way: "If...you can think about a thing inextricably attached to something else, without thinking of the thing it is attached to, then you have a legal mind." 45 A historian, on the other hand, must be able to see past events in their contemporary context, and this ability was one of Maitland's greatest gifts. In contrasting the two types of thinking he said:

44 Supra, pp. 67-70.

${ }^{45}$ This statement was made by Thomas Reed Powell, former law professor at Columbia and Harvard. Quoted in F. W. Maitland, Selected Writings, ed. R. I. Schuyler (Berkeley and Los Angelos: Untversity of California Press, 1960), pp. 10-11. 
That process by which old principles and old phrases are charged with a new content, is from the lawyer's point of view an evolution of the true intent and meaning of the old law; from the historian's point of view it is.... process of perversion and misunderstanding. 46

Maitland belleved that the study of law was a useful part of the legal historian's training, but that it should not be isolated from other studies.

Those critics who know his work well consider Maitland to be England's greatest historian. 47 The fact that so little is known of him by the public is due chiefly to the nature of his subject. "Law was his guiding Ifght; and the legal approach to history is too impersonal for the average reader." 48 "Maitland was a dedicated scholar, and except for contacts with his family and friends, most of his time was spent in historlcal research, writing, and activities connected with the University and his work.

He came naturally by his historical gifts. His paternal grandfather, Samuel Roffey Maitland, left the legal profession to take holy orders and to become Librarian to the Archbishop of Canterbury. After his retirement to his small estate in Gloucestershire he wrote religious history, which Maitland 1ater described as 'great.' He appreclated the critical way in which Samuel tested evidence and particularly admired his historical method. Samuel was a 'historical relativist' long

46 Maitland, "Why the History of English Law Was Not Written," Selected Writings, p. 137.

${ }^{47}$ F. M. Maitland, Selected Histortcal Essays intro. Helen Cam (Cambridge: University Press, 1957), p. ix; Maitland, Selected Writings, pp. 1-2; H. E. Bell, p. 2; William lloldsworth, Some Makers of English Law (Cambridge: University Press, 1966), p. 279.

$$
48 \mathrm{Maltl} \text { and, Selected Essays, p. } x \text {. }
$$


before that term was invented; he realized that institutions of the past could be understood only when viewed in their context. ${ }^{49}$ It was this method which Maitland himself used so successfully; he had an uncanny ability to view the history of a period as though he had witnessed it. Leslie Stephen once remarked that he sometimes feared "Maitland had got permanently into the wrong century." 50

At Cambridge Maitland came under the Influence of Henry Sidgwick, who Inspired him to read widely in philosophy. In the field of law he read Stubbs' Constitutional History and found it both interesting and persuasive. 51 He was greatly impressed by Savigny's Geschichte des Römischen Rechts, and he was acqualnted with the works of Brunner and Jacob Grimm. His interest in German jurisprudence led to his translation of the third volume of Gierke's Das deutsche Genossenschaftsrecht. Maitland did not care for narrative history, such as that of Gardiner; his own style of writing was analytical and explicative.

He did not read the usual histories of the period, probably because he was so absorbed in his own specialty. When Lord Acton, Regius Professor of Modern History at Cambridge, undertook to direct the writing of the Cambridge Modern History and asked Maitland to write a chapter on "The Anglican Settlement and the Scottish Reformation," Maitland wrote to him:

${ }^{49}$ Maitland, Selected Writings, p. 6. $50 \mathrm{H}$. E. Bell, p. 11 .

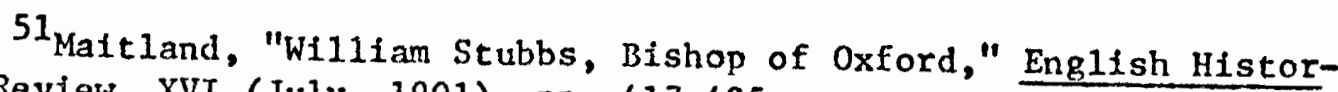
ical Review, XVI (July, 1901), pp. 417-425. 
Though you may guess a good deal, you cannot know the depth of my ignorance. I have hardly so much as heard that there was a Queen Elizabeth. Until I was thirty years old and upwards I rarely looked at a history-except histories of philosophy, which don't count--and since then I have only 'mugged up, as the undergraduates say, one subject after another which happened to interest me. 52

He did, however, write the chapter.

Perhaps to a greater extent than Vinogradoff, Maitland was enmeshed in the ideas and scholarly disputes of the academic and Intellectual circles in which he moved; Leslie Stephen, H. A. L. Fisher, J. H. Round, F. M. Pollock, R. L. Poole, P. G. Vinogradoff, are names we meet frequently in his letters and blographies. In addition he corresponded with well-known legal scholars, such as M. M. Bigelow and J. B. Ames, in the United States, where at the time there was great interest in legal history. This exchange of ideas was important in several ways: it shaped his political and religious thought, and influenced both the cholce of subject matter for his writings and his approach to 1 t.

Thus the interests and Influences in Maftland's life were chiefly intellectual, scholar1y, and conservative. He was not involved in politics and community affairs in any meaningful way; and in religious matters, though a member of the Church of England, he apparently was an agnostic. 53 Because of his poor health, Mattland knew he would not have the normal span of years in which to complete his work. Perhaps to compensate he worked at top speed and with unusual dedication:

$$
\begin{aligned}
& 52 \text { Fifoot, pp. } 214-15 \text {. } \\
& 53 \text { Ibid. p p. 179-81. }
\end{aligned}
$$


There was no Indian summer to his life--only the consciousness of the mass of work to be done and of the short time left to do it. 54

\section{William Ashley}

Ashley, we have seen, was born to lower middle class parents, who were poor, hard working, and purttantcal in their religious beliefs. He attended Oxford on a scholarship, and earned honors in history; his education was completed in Germany, where he became acquainted with the doctrines of the historical school of economics. As a professor of economic history he taught in Canada, the United States, and England. He was an innovator in making economics a practical discipline and in establishing schools of comerce abroad and at home. 55

In tracing the development of Ashley's thought we can find several determinative factors. The first was the econounc insecurity of his family which made him aware of the conditions of the laboring class and gave him first hand knowledge of the need for reform. His poverty acted as a spur to his efforts to secure a first class education, both as a means of bettering his own condition and as a tool to fight for the Improvement of the economic plight of others; it imbued him with a distrust of theoretical economics and, in the long run, determined the direction his career was to take. Thus he gave up the life of a historical scholar to engage in the more practical task of making economic knowledge available to the ordinary businessman. For Ashley

$$
\begin{aligned}
& 54 \text { Be11, p. } 6 . \\
& 55 \text { Supra, pp. 77-80. }
\end{aligned}
$$


this seems to have been a decision based on philosophical grounds as well as his own financial position. 56

Secondly, from the evangelical and puritanical background of his family life "he derived not a rigid code of conduct but a lasting conviction of ultimate good and of a purpose in the universe." While he accepted the Darwinian theory of evolution, that belief was combined with falth in a final goal; evolution meant change, but change for the better. 57 Like Seebohm, his faith included the moral directive that his knowledge, as well as his other gifts, must be used primarily for the benefit of others. This tenet for Ashley was not a form of sentimental humanitarianism, but one which had to be implemented by planned action and hard work. In an address entitled "The Christian Outlook: Sermons of an Economist," he said: "The union of knowledge with an active regard for the well-being of our fellows is the most difficult of human ideals. "58

Ashley's years at 0xford were 1mportant ones in his development. His IIfe there reinforced his sense of disparity between the classes in England.

... a distinguished oxford tutor... remarked that his knowledge of the "Proletariate" was derived exclusively from the observation of his college scout. I have sometimes thought of late that the notions of the laboring classes entertained by the

${ }^{56}$ Supra, pp. $79-80$.

57 MacDona1d, pp. 22-24. ${ }^{58}$ Quoted, Ibid., p. 22. 
barristers who write for the papers are derived from their contemplation of the laundresses in their chambers. 59

Further, his studies brought him under the influence of men whose doctrines shaped his own thought--Stubbs, whose work he knew through his reading, Arnold Toynbee and Gustav Schmoller, under whom he studied. Reflecting the strong influence of the historical school of economics in Germany, he held that economic theories and institutions could be judged only in relation to their own time; no economic theory could prevail for an indefinite period.

Modern economic theories are... not universally true; they. are true neither for the past, when the conditions they postulate did not exist, nor for the future when, unless society becomes stationary, the conditions will have changed. 60

A final factor in the development of Ashley's thought was his belief in the importance of economic history, which became both an integral part of his philosophical attitudes and a guide for his activities.

I care for history and economic history in particular, because if tells me of the life of the people... One is bound constantly to generalize; to try to discover the meaning of institutions, their growth and decay, their relation to one another. And. thus one gets into the way of regarding the whole of human history as having a meaning, as not being purposeless, as moving to some goal... Therefore, it seems to me that the work of the Economist should be, (i) the investigation of economic history-no facts are too remote to be without significance for the present... and (ii) the examination of modern industrial iffe 'in the piece.' We can leave to the Cambridge people hairsplitting analysis of abstract doctrine. 61

\footnotetext{
${ }^{59}$ Ashiley, The Adjustment of Wages (London, 1903), pp. 10-11. Ibid.

${ }^{60}$ Ashley, Engilsh Economic History, pp. viii-ix.

61 From a letter to his wife (1881), quoted in MacDonald, p. 25.
} 
These beliefs led Ashley to reject the theories of both Adam Snith and Karl Marx as static and unrelated to spectific conditions. Classical economists, advocating the doctrine of laissez faire, were theordzing in a vacuum; what they advocated was simply a fiction, since real freedom of contract between employers and employees was nonexistent. These men never examined the effects of their doctrines In actual operation; such an examination would prove how far their Idealized statements were from reality. His criticism of Marx was much like that made by Vinogradoff. ${ }^{62}$ Marx's theory of value was wrong, and the evolution of social and economic institutions involved many more factors than class warfare; the practices of private Industry and the policies of government were important, and should involve participation of all classes.

In this opinion can be seen not only Ashley's economic doctrines but also his bellef in the progress of mankind toward a more perfect society. The chief moving force behind his work thus appears to be his consciousness of the soctal and economic differences between the classes in England and his desire to minimize them. Ashley was never the retiring scholar, but always an active man in his church, in politics, and in government, as well as in his own profession.

${ }^{62}$ Vinogradoff's and Ashley's interpretation of Marx's doctrines was the traditional one unt11 1930 when his early works were published. Since then most Marxian scholars have held that the narrow economic determinist explanation is too simply to account for the many aspects of Marx's thought. 
CHAPTER V

\section{CONCLUSION}

What was the predominant form of landholding at the beginning of the Anglo-Saxon period in England? Did people living together in small communities own the land in common, sharing some of $1 t$, cult1vating part of it individualiy? Or was it owned by large landholders and Inhabited by a servile populace who.cultivated it for the benefit of a lord and received for their own use only a bare subsistence? We have examined closely the answers of four late 19th century historlans to this question.

Faul Vịnogradoff and Frederic Maitland were reasonaily certaín the early English peasant was free. Frederic Seebohm and William Ashley contended he could only have been a serf. We have presented in some detall their arguments, their methods, and factors in their background and lives which might have influenced their points of view. What can be found in all of this to explain their differences? While it is adaitted that in an analysis of this kind nothing can be stated with certainty, some conclusions can be offered.

Each of these men had available to him the same evidence, but none of them used it in the same way. To some extent they all employed the same method of examining the evidence, that is, they "read history backwards" and tried to construct from the more abundant evidence of later periods what must logically have preceded in earlier times, for 
which evidence was scarce or nonexistent. There were, however, definite differences of selection, emphasis, and interpretation.

Both Seebohm and Ashley felt it was important to establish some continuity between the landholding arrangements of the German tribes settling England and those of the early English peoples. Neither could find any proof of the existence of the Mark in Germany, and the problem of tracing the origin of fleld patterns turned out to be impossible to solve. Vinogradoff was not concerned at all with the German Mark or with the possible German origin of English field patterns. Maitland believed the open field system could only have been brought by the Teutonic invaders but did not attempt to deal with the technicalities of the problem.

Another obvious point of difference in the interpretation of the evidence is the emphasis Seebohm and Ashley placed on the economic aspects of the problem, and the equal emphasis Vinogradoff and Maitland placed on its legal aspects. This is not at all surprising in view of the spectalities of these men. Seebohm was an untrained historian, interested in what was "before his eyes," that is, the remnants of the open fields, and concerned with the economic rather than the legal aspects of the documents he examined. Ashley, on the other hand, spent some time carefully examining the legal records, but he felt they were apt to confuse rather than claxify the picture of early institutions. As an economic historian and a man who distrusted theory, he was more interested in the actual living conditions of the peasants than their legal status. 
In contrast, both Vinogradoff and Maitland firmly believed that the critical evidence of the history of the period were the legal records, and that upon them depended any possible clarification of pre-existing conditions. Further, they both were trained in 1 aw and in the techniques of legal analysis. Their methods of attacking a problem reflected this training, and this was especially true of Vinogradoff. They were more objective, more logical, and particularly more analytical in their handing of materials than were Seebohm or Ashley. 'Survivals of freedom' were easier to detect under this method than by a general approach.

However, we cannot say that the legal evidence points only. to freedom and the economic evidence points only to serfdom, for none of it is completaly. clear and all of $1 t$ is subject to more than one interpretation. We should consider the possibility, therefore, that each historian emphasized the type of evidence most fainilar to him, but reached a conclusion which might have been his regardless of the kind of evidence he used in his investigation. This would indicate that the types of evidence do not tell different stories, but that the historian regarded the problem from a predetermined point of view. In that case we must search for possible prejudices.

In looking at the lives of Seebohm and Ashley a number of similarities are apparent. Both of them suffered some economic deprivation In their youth, leaving them with an awareness of the very real problems poverty presents. Both were members of evangelical faiths which taught duty and responstbility toward all mankind, and each engaged in activities to promote the welfare of the working class. Though 
certainly neither was a radical in the Marxian sense, both were more interested in trying to change the world than in theorizing about it; they could be loosely called 'radical 11berals.' Both apparently were confident of man's innate goodness and tempered their acceptance of Darwinism with the belief that evolution meant change for the better. Ashley's daughter has said that this belief made it impossible for him to accept the theory that the manorlal system had begun as a free village community "because he could not believe that a free comunity could have ever sunk into serfdom." 1 Perhaps the same could be sald of Seebohm.

In contrast to Seebohm and Ashley both Vinogradoff and Maitland came from economically secure backgrounds, where great value was placed on education and scholarship. Neither was actively religious; they were members of orthodox faiths but appear to have shared the doubts of many late Victorian intellectuals, to whom Darwin's theory of evolution meant the destruction of the concept of man's uniqueness without implying that change could only be change for the better. Neither was active in politics in England, but both were basically 'conservative liberals.' Vinogradoff's efforts in Russia had been directed toward educational and constitutional reform, which he felt had to precede any lasting economic improvement for the lower classes. Vinogradoff once suggested that the answers which had been given to the question of the status of the English peasant might have political implications. He thought Maine and Stubbs, presenting the $1_{\text {MacDonald, p. } 24 .}$ 
Germanist point of view, could be called liberals, while Seebohm, advocating the Romanist position, was possibly a conservative. Maitland pointed out to him that Maine and Stubbs were 'pillars of conservatism' and that it was hard to find political implications in Seebohm's work. 2 In this we can find a clue to Vinogradoff's own bastc position. He did not think of himself as a conservative, yet he had a deep distrust of revolutionary movements born of his experiences in Russia, and an abiding fatth in the principle of individual freedom. His early training in Germany under men like Brunner had convinced him of the primitive democracy of the early German tribes; and his admiration for England's constitutional government, combining order with Individual freedom, equaled that of any Englishman. It was intellectual attitudes of this kind which had characterlzed the Germanists in England since the problem of the beginnings of the common man was first debated there.

In sumary we can say that a previously formed intellectual blas was the chief factor influencing the historians we have studied to declde whether the early English peasant was a freeman or whether he was a serf. It was this bias which led inevitably to different conclusions in spite of the fact that the same evidence was avallable to them all. Other factors, contributing to a lesser.extent to the formation of opposing views, were different methods of inquiry and special historical interests which guided both the selection of material and its analysis.

${ }^{2}$ Supra, pp. 113-14. 
Although it appears to be insoluble, the problem of original freedom remalns an important one in English history and will undoubtedly continue to intrigue future historians as it has those of the past; for as Ashley has said, any historical theory of the "government of the nation" must rest "consciously or unconsclously on some view as to the position of the body of the people." 3

${ }^{3}$ Ashley, "The English Manor," p. vil: 


\section{BIBLIOGRAPHY}

Ashley, William J. The Economic Organization of England. London: Longmans, 1914.

- An Introduction to English Economic H1story and Theory. 2 vols. 2nd ed. London: Longmans, 1892. - Surveys, Historic and Economic. New York: Augustus M. Kelly, 1966.

- "The Character of Villein Tenure," Annals of the American Acadeny of Political and Social Sctence. I (1890-01), 412-25. - "The Origin of the Manor," Introduction to N. D. Fustel de Coulanges, The Origin of Property in Land. London: George Allen \& Unwin, $19 \overline{27}$.

Be11, Henry E. Mattland. Cambridge, Mass.: Harvard University Press, 1965.

Be11, John F. A History of Economic Thought. New York: Ronald Press Co., 1953.

Blair, P. Hunter. An Introduction to Anglo-Saxon England. Cambridge: University Press, 1962.

Bloch, Marc. Feudal Soclety. Chicago: Untversity of Chicago Press, 1968.

- French Rural History. Translated by Janet Sondheimer. Berkeley, Calif.: University of California Press, 1966.

Boorstin, D. J. "Tradition and Method in Legal History," 54 Harvard Law Review 424 (January, 1941).

Bracton, Henry. On the Laws and Customs of England. Edited by G. E. Woodbine. Cambridge, Mass.: Harvard University Press, 1968.

Butterfield, Herbert. The Englishman and his History. U.S.A.: Archon Books, 1970.

- The Whig Interpretation of History. New York: W. W. Norton \& Co., 1965 .

Caesar, C. Jullus. De Bello Gallico. Translated by H. J. Edwards. London: William Heinemann, Ltd., 1946. 
Carpenter, William S. Foundations of Modern Jurisprudence. New York: Appleton-Century-Crofts, 1958.

Chadwick, Hector $M$. The Origin of the English Nation. Cambridge: University Press, 1907.

Cole, G. D. H. British Working Class Politics, 1832-1914. London: George Routledge \& Sons, 1941. - Socialist Thought, Marxism and Anarchism, 1850-1890. London: Macmillan \& Co., 1961 .

Collingtrood, F. B. A. and Myres, J. N. L. Roman Britain and the English Settlements. Oxford: Clarendon Press, 1968.

Denman, D. R. Origins of Ownership. London: George Allen \& Unwin, 1958.

D111on, John F. "Bentham's Influence in the Reforms of the Nineteenth Century," Association of American Law Schools (ed.), Select Essays in Anglo-American Legal History. 3 vols. Boston: Little, Brown \& Co., 1907. I: 492-515.

Dopsch, Alfons. The Economic and Social Foundations of European Civilization. London: K. Paul, Trench, Trubner \& Co., 1937.

Duby, Georges. L'Economie rurale et la vie des compagnes dans 1 'occident médiéval. 2 tomes. Paris: Aubier, 1962.

Earle, John. A Hand-Book to the Land Charters, and Other Saxonic Documents. Oxford: Clarendon Press, 1888 .

Ensor, R. C. K. England 1870-1914. Vol. XIV of The Oxford History of England. Edited by G. N. Clark. Oxford: Clarendon Press, 1966.

Fifoot, C. H. S. Frederic William Maitland, A Life. Cambridge, Mass.: Harvard University Press, 1971.

Finberg, H. P. R. (ed.). The Agrarian History of England and Wales, A. D. 43-1042. Cambridge: University Press, 1972.

Finn, R. Welldon. The Domesday Inquest and the Making of Domesday Book. London: Longmans, 1961.

- Domesday Studies: The 'Liber Exoniensis'. London: Wm. Clowes \& Sons, 1964.

Fisher, H. A. L. "Paul Vinogradoff, a Memoir," The Collected Papers of Paul Vinogradoff. Vol. I. Oxford: Clarendon Press, 1928. 
Freeman, Edward A. The History of the Norman Conquest of England. 6 vols. Oxford: Clarendon Press, 1877-79.

Friedrich, Carl J. The Philosophy of Law in Historical Perspective. Chicago: University of Chicago Press, 1963.

Furneaux, Henry. Cornelii Tacit1 de German1a. Oxford: Clarendon Press, 1894.

Fustel de Coulanges, Numa Denis. The Origin of Property in Land. Translated by Margaret Ashley. London: George Allen \& Unwin, 1927.

Galbraith, V. H., The Making of Domesday Book. Oxford: Clarendon Press, 1963.

Ganshof, F. L. Feudalism. London: Longmans, 1952.

Gide, Charles and Rist, Charles. A History of Economic Doctrines. Translated by R. Richards. 2nd ed. Boston: D. C. Heath \& Co., 1948.

Gierke, Otto. Political Theories of the Middle Ages. Translated by F. W. Maitland. Cainbridge: University Press, 1968.

Glanville, Treatise on the laws and customs of the realm of England. Edited by G. D. G. Hall. London: Thomas Nelson \& Sons, 1965.

Glendinning, Victoria. A Suppressed Cry: Life and Death of a Quaker Daughter. London: Routledge \& Kegan Paul, 1969.

Gooch, G. P. History and Historians in the Nineteenth Century. London: Longmans, 1952 .

Gras, N. B. S. "Stages in Economic History," Journal of Economic and Business History, II (May, 1930), 395-418.

Gray, Howard L. English Field Systems. Cambridge, Mass.: Harvard University Press, 1959.

Green, John Richard. A Short History of the English People. New York: Harper \& Bros., 1893.

Guizot, François. A Popular History of France. Translated by Robert Black. 6 vols. Boston: Dana Estes \& Charles E. Laureat, 1870.

Halevy, Elie. A History of the English People in the Nineteenth Century. Translated by F. I. Watkin \& D. A. Barker. 6 vols. 2nd ed. London: Ernest Benn, 1924-51. 
Haney, Lewis H. History of Economic Thought. 4 th ed. New York:

Hardin, D. B. (ed.). Dark-Age Brltain. London: Methuen \& Co., 1956. Haverfield, R. The Romanization of Roman Britain. Oxford: Clarendon Press, 1923.

Hilton, R. H. The Decline of Serfdom in Medieval England. New York: St. Martin's Press, 1969.

Hodgkin, R. H. A History of the Anglo-Saxons. 2 vols. 3rd ed. London: 0xford Universicy Press, 1952.

Hogue, Arthur R. Origins of the Common Law. Bloomington, Ind.: Indiana University Press, 1966.

Holdsworth, William. The Historians of Anglo-American Law. Hamden,

Conn.: Archon Books, 1966. igs A History of English Law. 16 vols. London: Methuen \& Co., - Some Makers of English Law. Cambridge: University Press,

Hone, Nathaniel J. The Manor and Manorial Records. Port Washington, N. Y.: Kennikat Press, 1906.

Houghton, Walter E. The Victorian Frame of Mind. New Haven \& Iondon: Yale University Press, 1971

Hueber, Rudolph. History of Germanic Prlvate Law. Translated by F. S. Philbrlck. New York: Augustus M. Kelly, 1968.

Jolliffe, J. E. A. A Constitutional History of Medieval England from the English Settlement to 1485. London: Adam and Charles Black, 1961.

Jolowica, H. F. Historical Introduction to the Study of Roman Law. Cambridge: University Press, 1967.

Kantorwicz, Hermann. "Savigny and the Historical School of Law," 53 Law Quarterly Review 334 (1937).

Kemble, John M. The Saxons in England. 2 vols. London: Longmans, 1849.

Lennard, Reginald. Rural England, 1086-1135. Oxford: Clarendon Press, 1959. 
"The Economic Position of the Domesday Villani," Economic Journal, 56 (June, 1946), 244-264.

- "The Economic Position of the Domesday Sokemen," Economic Journal, 57 (June, 1947), 179-195.

Lipson, E. The Economic History of England. 3 vols. 12th ed. New York: Barnes \& Noble, 1959.

Loyn, H. R. Anglo-Saxon England and the Norman Conquest. London: Longmans, 1962 .

MacDonald, Janet. "Sir William Ashley (1860-1927)," B. E. Schmitt (ed.), Some Historians of Modern Europe. Port Washington, N. Y.: Kennikat Press, 1942.

Maine, Henry S. Ancient Law. London: Oxford University Press, 1931. - Lectures on the Early History of Institutions. Port Washington, N. Y.: Kennikat Press, 1966.

- Village Communities in the East and West. London: John Marry, 1871 .

Maltland, Frederic W. The Constitutional History of England: Cambridge: University Press, 1908.

- Domesday Book and Beyond. London: Collins, 1969.

- The Forms of Action at Common Law. Cambridge: University Press, 1968.

- Historical Essays. Edited by Helen Cam. Cambridge: University Press, 1957 .

- Letters. Edited by C. H. S. Fifoot. Cambridge, Mass.:

Harvard University Press, 1965.

- Selected Essays. Edited by H. D. Hazeltine, G. Lapsley, and P. A. Winfield. Freeport, N. Y.: Books for Libraries Press, 1968.

- Selected Writings. Edited by Robert L. Schuyler. Berkeley, Calif.: University of California Press, 1960.

- Township and Borough. Cambridge: University Press, 1964.

- "The Mystery of Seisin," 2 Law Quarterly Review 481, (1886). 
"William Stubbs, Bishop of Oxford," English Historical Review,
XVI (July, 1901), 417-426.

Malakov, Basil. "Vinogradoff," The Slavonic and East European Review, XIII (April, 1935), 633-40.

McClelland, Charles E. The German Historlans and England. Cambridge: University Press, 1971.

Orwin, C. S. and Orwin, C. S. The Open Fields. Oxford: Clarendon Press, 1967.

Petrie, Charles. The Victorians. New York: David Mckay Co., 1961.

Pollock, Frederick. The Land Laws. London: Macmillan \& Co., 1883.

- "English Law Before the Norman Conquest," Association of American Law Schools (ed.), Select Essays in Anglo-American Legal History. 3 vols. Boston: Little, Brown \& Co., 1907. I: 88-107.

Pollock, Frederlck, and Maltland, Frederic W., The History of English Law Before the Time of Edward I. 2 vols. 2nd ed. Cambridge: University Press, 1952 .

Pospisil, Leopold. Anthropology of Law. New York: Harper \& Row, 1971

Richardson, H. G., and Sayles, G. O. Law and Legislation from Aethe1berht to Magna Carta. Edinburgh: University Press, 1966.

Ross, Denman W. The Early History of Land-Holding Among the Germans. Boston: Soule \& Bugbee, 1883.

Round, John H. Feudal England. London: George Allen \& Unwin, 1964. - "The Domesday Manor," English Historical Review, XV (April, 1900), 293-302.

Sayles, George 0. The Medieval Foundations of England. London: Meuthen \& Co., 1956.

Schapiro, J. Salwyn. Liberalism and the Challenge of Fascism (Social Forces in England and France, 1815-1870). New York: McGrawHil1 Book Co., 1949.

Schultz, Harold J. History of England. 2nd ed. New York: Barnes \& Noble, 1971.

Scott, William R. "Memolr: Sir William Ashley," Economic History Review, Series 1, I (1927), 319-21 
Seebohm, Frederic. The Era of the Protestant Revolution. New York: Charles Scribner's Sons, 1904 .

- The Eng1ish Village Cormunity. Port Washington, N. Y.:

Seton-Watson, Hugh. The Decline of Imperial Russia, 1855-1914. New York: Frederick A. Praeger, 1965.

Simpson, A. W. B. An Introduction to the History of the Land Law. London: Oxford University Press, 1961.

Slicher van Bath, B. H. The Agrarian History of Western Europe A. D. 500-1850. London: Edward Arnold, 1963.

Smellie, K. B. "Sir Henry Maine," Economica, VIII (1928) 64-94.

Somervell, D. C. English Thought in the Nineteenth Century. London: Methuen \& Co.. 1957.

Stenton, Frank M. Anglo-Saxon England, c. 550-1087. Vo1. II of The Oxford History of England. Edited by G.N. Clark. Oxford: Clarendon Press, 1947.

- The Free Peasantry of the Northem Danelaw. Oxford: Clarendon Press, 1969.

Stephenson, Carl. Medieval Institutions, Selected Essays. Edited by Bryce D. Lyon. Ithaca, N. Y.: Cornell University Press, 1967.

Stone, Julius. The Province and Function of Law. Cambridge, Mass.: Harvard University Press, 1961.

Stubbs, William. Constitutional History of England. 3 vols. Oxford: Clarendon Press, 1874-78.

Tacitus, C. Dialogus, Agricola, Germania. Translated by Maurice Hutton. Cambridge, Mass.: Harvard University Press, 1963.

Tait, James. "Large Hides and Small Hides," English Historical Review, XVII (Apri1, 1902), 280-82.

Thaden, Edward C. Russia since 1801. New York: John Wiley \& Sons, 1971.

Thierry, Augustin. Récits des temps Merovingiens. Paris: Union generale d'editions, 1965 .

Thomson, David. England in the Nineteenth Century, 1815-1914. London: John Cape, 1950. 
Thompson, James W. A H1story of Historical Writing. 2 vols. New York: Macmilian \& Co., 1942 .

Tompkins, Stuart $R_{0}$ The Russian Intelligentsia. Norman, Okla.: University of Oklahoma Press, 1958.

Venturi, Franco. The Roots of Revolution. New York: Alfred A. Knopf, 1960.

Vinogradoff, Paul G. Collected Papers. Edited by H. A. L. Fisher. 2 vols. Oxford: Clarendon Press, 1.928. English Society in the Eleventh Century. Oxford: Clarendon Press, 1908 . 195 The Growth of the Manor. London: George Allen \& Unwin, - Outlines of Historical Jurisprudence. 2 vols. London: Oxford University Press, 1920. . - Roman Law In Medieval Europe. Cambridge: Speculum Historiale, 1968.

- Russia. the Psychology of a Nation. (Oxford Parphlets, 1914). London: Oxford University Press, 1914.

- Self-Government in Russta. London: Constable \& Co., 1915.

- The Teach1ng of Sir Henry Maine. London: Henry Frowde, 1904.

- Villainage in England. Oxford: Clarendon Press, 1968.

- "Folkland," English Historical Review, VIII (January, 1893), 1-17.

- "Frederic William Maitland," English Historlcal Review, XXII (Apri1, 1907), 280-289.

Walkin, Jacob. The Rise of Democracy in Pre-Revolutionary Russia. New York: Frederick A. Praeger, 1962.

Whitelock, D. M. The Beginnings of English Society. Baltimore, 1966.

Willson, David H. A History of England. New York: Holt, Rinehart \& Winston, 1967.

Woodward, E. L. The Age of Reform, 1815-1870. Vo1. XIII of the Oxford History of England. Edited by G.N. Clark. Oxford: Clarendon Press, 1946. 
Young, G. M. Vlctorian England. London: Oxford University Press, 1049. 